\title{
Intermountain West Military Training Lands Planting Guide: Selecting Seed Mixtures for Actively Used Military Lands
}

\author{
US Army Corps \\ of Engineers ${ }_{\circledast}$ \\ Engineer Research and \\ Development Center
}

Antonio J. Palazzo, Susan E. Hardy, Timothy J. Cary, Kay H.

June 2009

Asay, Kevin B. Jensen, and Daniel G. Ogle

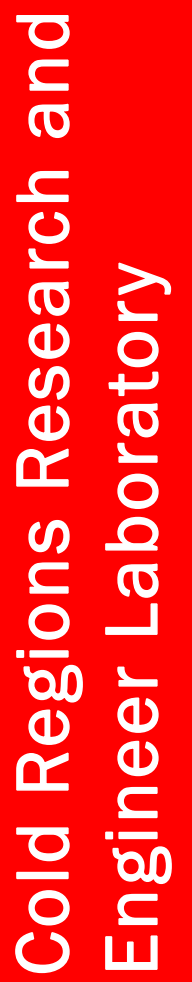

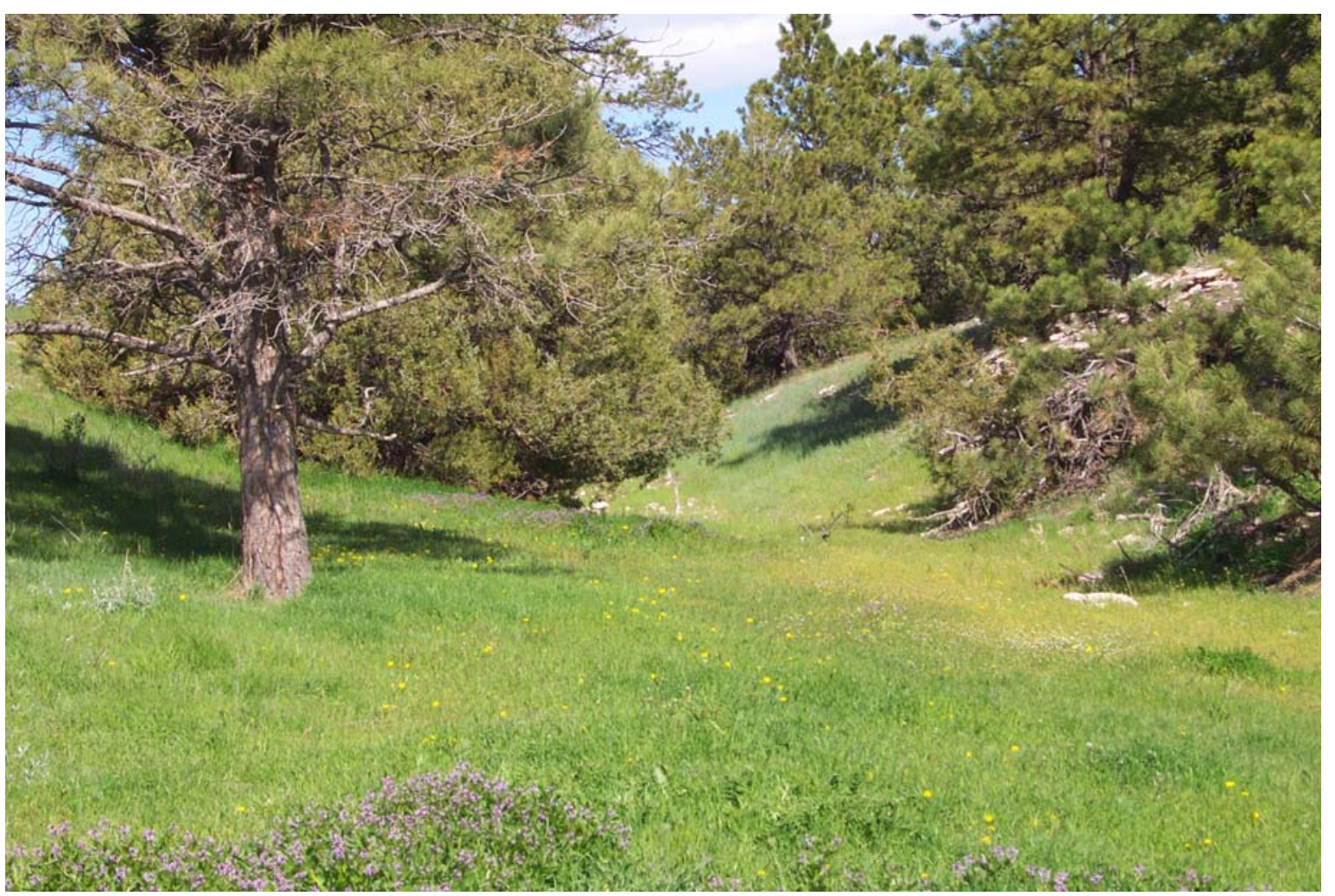




\title{
Intermountain West Military Training Lands Planting Guide: Selecting Seed Mixtures for Actively Used Military Lands
}

\author{
Antonio J. Palazzo, Susan E. Hardy, and Timothy J. Cary \\ Cold Regions Research and Engineering Laboratory \\ U.S. Army Engineer Research and Development Center \\ 72 Lyme Road \\ Hanover, NH 03755-1290
}

Kay H. Asay and Kevin B. Jensen

United States Department of Agriculture-

Agriculture Research Service

Logan, Utah

Daniel G. Ogle

United States Department of Agriculture-

Natural Resources Conservation Service

Boise, Idaho

Final report

Approved for public release; distribution is unlimited.

Prepared for The Army Environmental Command and

the Environmental Security Technology Development Program 


\begin{abstract}
These guidelines were prepared to help military land managers select appropriate seed mixtures for revegetation on actively used training lands in the Intermountain West of the United States. Recommending a seed mixture is complicated because of the various ecosystems, land uses, soils, and plant selection goals. We wanted to keep the guidelines as simple as possible but still be able to recommend seed mixtures adapted for this region. We have broken down the process into four steps that we feel cover the important aspects of selecting the most adapted seed mixture to meet revegetation goals on actively used lands such as training ranges, airfields, and MOUT sites. Tables provide information to assist in selection of species to include in seed mixtures for various soil types, climates, and land usage. Characteristics of the militarily important plants mentioned in this guide are also given. This information is provided in two appendices containing a summary table and individual plant description sheets.
\end{abstract}

DISCLAIMER: The contents of this report are not to be used for advertising, publication, or promotional purposes. Citation of trade names does not constitute an official endorsement or approval of the use of such commercial products. All product names and trademarks cited are the property of their respective owners. The findings of this report are not to be construed as an official Department of the Army position unless so designated by other authorized documents. 


\section{Contents}

Figures and Tables

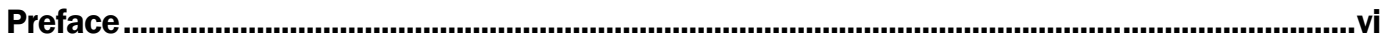

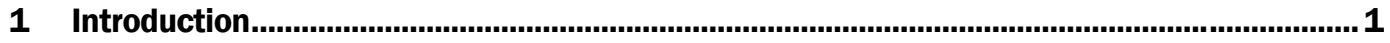

1.1 Purpose of Guidelines ....................................................................................... 1

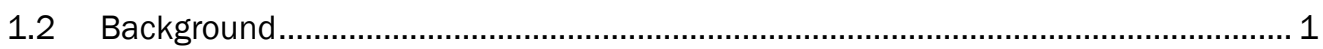

1.3 Military Facilities in the Intermountain Region .............................................. 3

1.4 Using these Guidelines............................................................................... 4

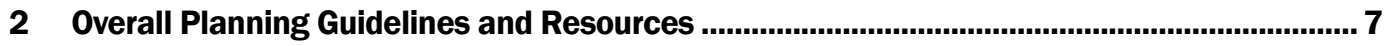

2.1 Requirements and Funding ............................................................................ 7

2.2 Preliminary Questions for Site-specific Planning ............................................... 8

What are your land management goals? .............................................................................. 8

What future level (severe, moderate, or light) of land use or training do you expect? ............ 8

Is revegetation necessary? ............................................................................................... 8

What are the site-specific plant establishment constraints? ................................................ 8

What desirable plant species are already on the site? ........................................................ 9

Which, if any, invasive plant species are present? ................................................................ 9

2.3 Some Plant Physiological Characteristics Important to Military Training

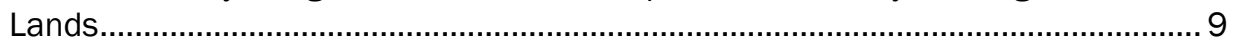

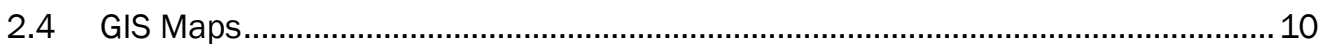

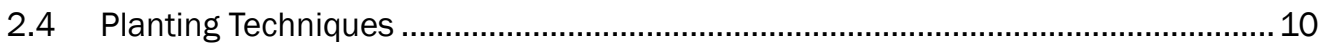

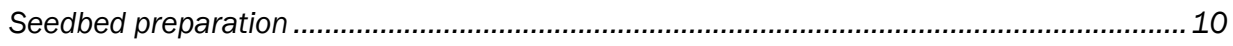

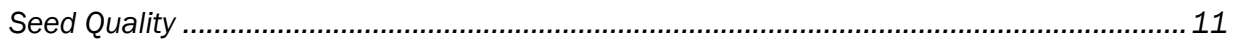

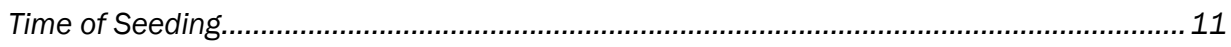

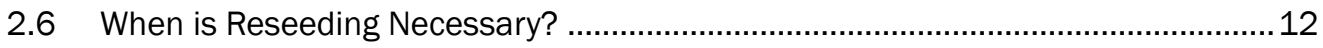

2.7 Source Materials.............................................................................................. 12

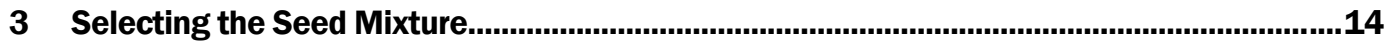

3.1 Identify Ecosystem and Annual Precipitation................................................... 15

3.2 Describe the Soil Texture ................................................................................. 15

3.3 Identify the Training Level or Land Use ............................................................... 16

Intensive land use on range and training areas.................................................................. 16

Light and moderate land use on range and training areas ................................................ 17

MOUT sites, small-arms ranges, airfields, and roadsides.................................................. 17

3.4 Select and Refine the Seed Mixture ..................................................................... 18

Seed mixtures dominated by or entirely of introduced species (I) ....................................... 19

Seed mixtures dominated by or entirely of native species $(N)$........................................... 19

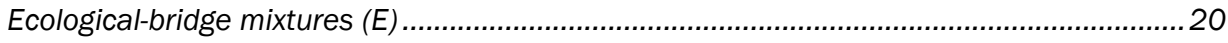

References 


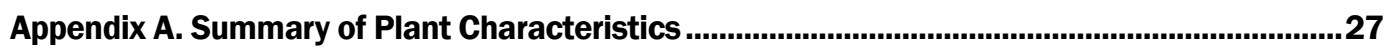

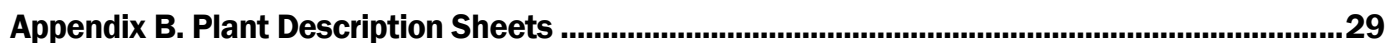

Report Documentation Page 


\section{Figures and Tables}

\section{Figures}

Figure 1. Map of Intermountain West including military facilities.

Figure 2. Factors affecting revegetation; different types of ecosystems, land use, and soil type require different types of vegetation

Figure 3. Soil texture classifications (from USDA-NRCS). The colored areas indicate the two broad classifications used in this guide: sand (blue) and silt/clay (yellow).

\section{Tables}

Table 1. Plant density guide.

Table 2. Suggested species to include in seed mixtures for rangeland plantings in upland ecosystems.

Table 3. Suggested species to include in seed mixtures for rangeland plantings in semidesert ecosystems.

Table 4. Suggested low-growing grasses for military operations in urban training (MOUT) or small arms sites.

Table 5. Characteristics of selected grasses (from Monsen et al. 2004). 


\section{Preface}

This report was prepared by Antonio J . Palazzo, Susan E. Hardy, and Timothy J . Cary, Biogeochemical Sciences Branch, U.S. Army Engineer Research and Development Center (ERDC), Cold Regions Research and Engineering Laboratory (CRREL), Hanover, New Hampshire, and by Dr. Kay H. Asay (retired) and Dr. Kevin B. J ensen, United States Department of Agriculture-Agricultural Research Service (USDA-ARS), Logan, Utah.

The report was prepared under the general supervision of Dr. Terrence Sobecki, Chief, Biogeochemical Sciences Branch; Dr. Justin Berman, Division Chief; Dr. Lance Hansen, Deputy Director; and Dr. Robert E. Davis, Director, CRREL.

The Commander and Executive Director of ERDC is COL Richard B. J enkins. The Director is Dr. James R. Houston.

We acknowledge the funding support by Strategic Environmental Research and Development Program (SERDP) and the Environmental Security Technology Certification Program (ESTCP) programs, the Army Environmental Command (AEC), the National Guard Bureau, Fort Drum, the Army Command (ACOM), the Army Basic Research BT-25 Program, and the Wyoming National Guard. We also acknowledge the in-kind support in equipment and direction provided by land managers at the Yakima Training Center, Fort Carson, Camp Guernsey, and Dugway Proving Grounds. We also thank those at ERDC for helping in directing the research and providing support.

General guidance for the project was supplied by Dr. J effrey Marqusee, ESTCP Director, Brad Smith, SERDP Director, and Femi Ayorinde, Robert Holst, and J ohn Hall, Program Managers. The authors thank Kim Watts and Bonnie Packer, Army Environmental Command for supporting additional aspects of their research, both financially and technically.

We also thank HydroGeoLogic, Inc., contractor for the ESTCP program, for program support, includingJ ohn Thigpen, Carrie Wood, Kristen Lau, Lucia Valentino, J ennifer Rusk, and Susan Walsh. 
Over the life of this program, we have enjoyed and benefited from working with many people, including Dr. David Huff, Pennsylvania State University, and Dr. Blair Waldron and Dr. Steven Larson, USDA-ARS, Logan, Utah, who provided technical assistance, and Dan Ogle and Loren St. J ohn, USDA-NRCS Plant Materials Center, Aberdeen, Idaho, who helped with seed production. We also thank Nancy Shaw, US Forest Service, Bob Holst, HydroGeoLogic, Inc., George 'Rusty' Savoy, Fort Carson, Tom Vorac, ACSIM, and Stuart Cannon, ACOM ITAM Program Manager, for reviewing parts of this report.

Many ERDC people have helped to make this program a success, including Gary Pasternak who helped develop the memorandums of agreements between cooperating agencies. Technical support was provided by Nancy Perron, Dennis Lambert, and Troy Arnold at ERDC-CRREL and William Severinghaus, Robert Lacey, Alan Andersen, Dick Gebhart, and Ryan Busby at ERDC-CERL. 


\section{Introduction}

\subsection{Purpose of Guidelines}

This guide provides recommendations on plant materials for Department of Defense (DoD) training-land revegetation at military facilities in the Intermountain West of the United States (Figure 1). These guidelines fill a gap in knowledge in the science of military land management; there are no other guides for military training-land revegetation for land managers who manage these unique pieces of public property. Most other guides for land revegetation are for lands with little traffic and are usually related to either grazing or conservation lands; they are based primarily on plant

establishment. On grazing lands, animals selectively injure the plants, and the goal is to maintain stand persistence and production. On conservation lands, the sites are not disturbed to the same extent as military lands, and plants, usually native species, are allowed time to establish. On military lands, the degree and cause of disturbance can vary, but in general vegetation must establish as quickly as possible, be more resilient to military training activities, and preferably be native. We believe two of the more important characteristics of plants that contribute to resiliency on military lands are rapid establishment and the ability of the plant to spread into disturbed areas without being invasive to adjoining lands, including private lands.

\subsection{Background}

The information in these guidelines is partially based on the results of extensive research over about 10 years primarily at three military facilities (Yakima Training Center, Fort Carson, and Camp Guernsey) and on literature resources (J ensen et al. 2001, Monsen et al. 2004, and Palazzo et al. 1994). The research and related resources include plant breeding, monoculture and mixture seeding trials, and larger-scale demonstrations. The summaries of the research and demonstrations that were used to help develop these guidelines are reported in Palazzo et al. (2003) and Palazzo et al. (in preparation), respectively.

The objective of the research phase was to develop new germplasms and cultivars that are resilient to training activities and that are easier to establish on disturbed sites. Studies were conducted to provide 
information regarding the relationship between military training and plant injury, re-growth, and wear resistance. New plant germplasms and cultivars were developed under the SERDP project "Identify resilient plant characteristics and develop a wear-resistant plant cultivar for use on military training lands" (CS-1103) (Palazzo and Hardy 1998, Palazzo et al. 2003). In the plant breeding program, we were able to improve traits related to resiliency and establishment in introduced and native species of rangeland grasses. Selection criteria included early spring growth, increased seedling vigor, improved tiller and rhizome development after disturbance, and resistance to abiotic and biotic stresses.

Our modified plant materials are ecologically compatible to the military sites because they were developed on military sites and from collections of species native to or previously seeded at these sites. With SERDP, and also with Army Basic Research (BT-25) funding, we made significant advances in relating molecular markers to plant characteristics and in using DNA fingerprinting techniques to characterize genetic diversity. We used markers to identify species and plants that grow better at low temperatures. For genetic diversity, we now have the tools to assess the genetic differences and similarities in commercial and natural seed sources (Hu et al. 2001, Huff and Palazzo 1998, Huff et al. 1998, Larson et al. 2000, 2001, 2003, 2006).

Our modified species show promise for better resiliency on training lands. Our tank and Stryker traffic studies showed that introduced (naturalized) species are more tolerant to and recover more rapidly under repeated tracking than their native counterparts (Anderson et al. 2005, Palazzo et al. 2005). However, three of the natives we worked with-western wheatgrass, Sandburg bluegrass, and Snake River wheatgrass-showed promise as stabilization species because of their ability to colonize damaged areas. Our research on the "ecological bridge" concept confirms that we can select seed mixtures consisting of native and introduced species that will establish more rapidly than all-native mixes, allowing for earlier land-use training, and ultimately lead to healthy and persistent stands of native plants (Asay et al. 2001, Waldron et al. 2005, 2006a). Seed and equipment needed are readily available for seeding recommended seed mixtures, and the seeding can be done in one application, thus saving money. Our modified plant materials will make these seeding mixes even more desirable. 
In the demonstration phase, we evaluated the plant materials that we developed for use on military training lands. We developed procedures for release of cultivars and initiating seed contracts. We made four releases under the SERDP project and six more during the ESTCP project (see below). Three of the cultivars were put into production, and the seed was made available to six DoD facilities (Mountain Home Air Force Base, Idaho; Camp Guernsey, Wyoming; Fort Carson, Colorado; Yakima Training Center, Washington; Camp Williams, Utah; and Fort Riley, Kansas) for additional demonstrations in military land rehabilitation. Our ecological-bridge seeding methods further enhanced the ability of our modified cultivars to establish viable native plant stands as rapidly as possible and compete with invasive weed establishment. Our modified seeding methods have proven successful on eastern and western ranges (Fort Drum, New York; Yakima Training Center, Washington; and Fort Carson, Colorado).

The modified plant materials developed under these SERDP and ESTCP programs include the natives:

- Reliable Sandberg bluegrass, a selected-class germplasm (Waldron et al. 2006c)

- Yakima western yarrow, a source-identified germplasm (Waldron et al. 2006b)

- 'FirstStrike' slender wheatgrass cultivar, currently on the market for purchase (J ensen et al. 2007).

- 'Recovery' western wheatgrass cultivar, plant release nearing completion (description in preparation)

and introduced species:

- 'CD-II' crested wheatgrass cultivar, currently on the market for purchase (Asay et al. 1997)

- RWR-Tetra-1 Tetraploid wildrye, a source-identified germplasm (Jensen et al. 1998)

- 'Bozoisky-II' Russian wildrye cultivar (J ensen et al. 2006)

- 'Vavilov II' Siberian wheatgrass cultivar (J ensen et al. 2009)

\subsection{Military Facilities in the Intermountain Region}

These guidelines apply to the Intermountain West Region of the United States. As shown on the map in Figure 1, there were 42 military facilities in 
this region at the time our research began. Facilities under the Army Commands (ACOM, formerly Forces Command or FORSCOM) and Army Materiel Command (AMC) included over one million acres. Counting facilities over 5,000 acres, the National Guard Bureau managed over 375,000 acres at 13 facilities. There were 11 Air Force facilities in this region with about 133,000 additional acres, not including Nellis Air Force Base with a total of 3.5 million acres. There were also 10 Navy facilities in this region. Smaller DoD facilities were not included in this list.

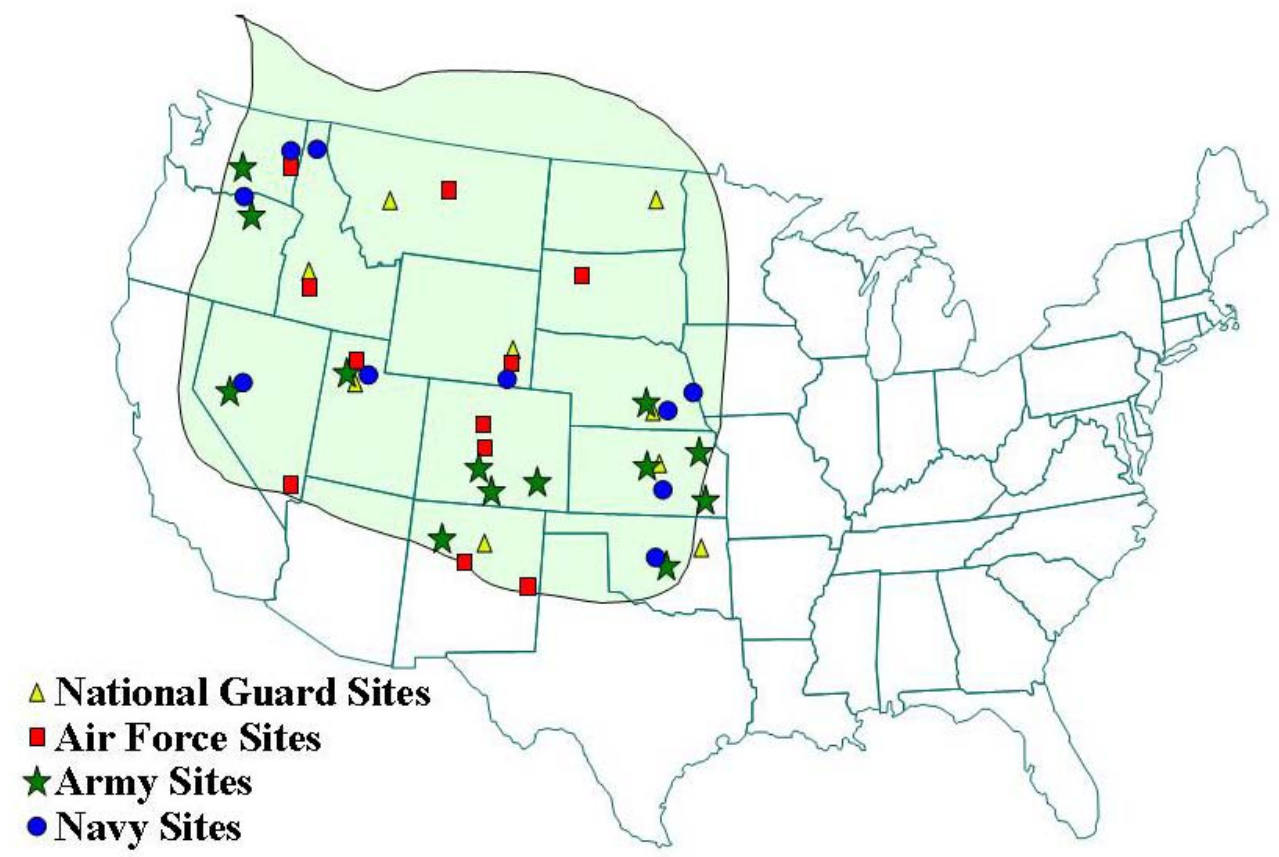

Figure 1. Map of Intermountain West including military facilities.

\subsection{Using these Guidelines}

The revegetation goals on DoD military facilities are very diverse and are directly related to land use, soil type, and local environment (Figure 2). Military lands are disturbed in many different ways, making it difficult to write a simplistic guide on land revegetation. These guidelines briefly describe the planning process and revegetation methods that should be considered, but the primary focus is on selection of species that should be used in revegetation projects. Information on planting equipment is not part of this guide; information can be found at other locations including the web site: http://reveg-catalog.tamu.edu/. 

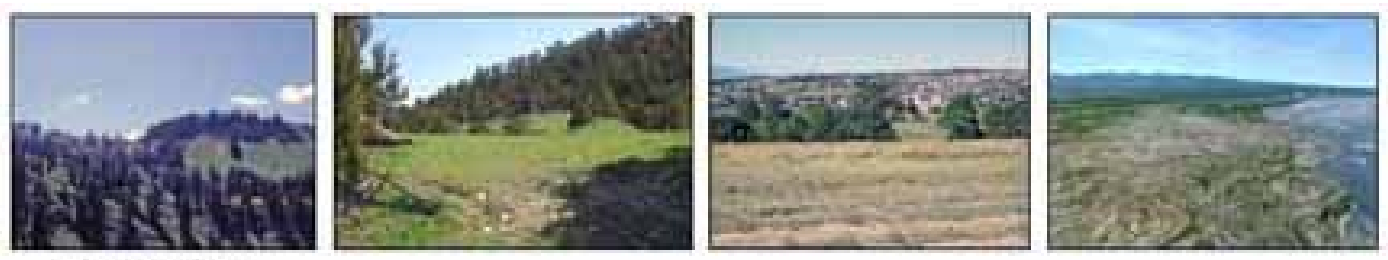

Ecosystem
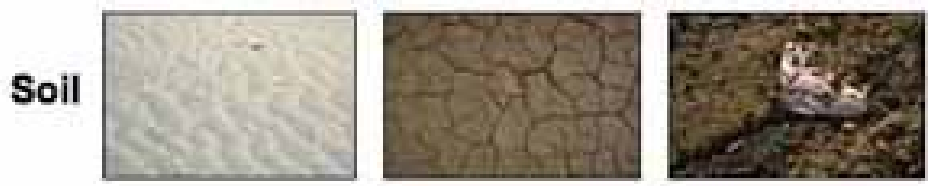

\section{Land use}
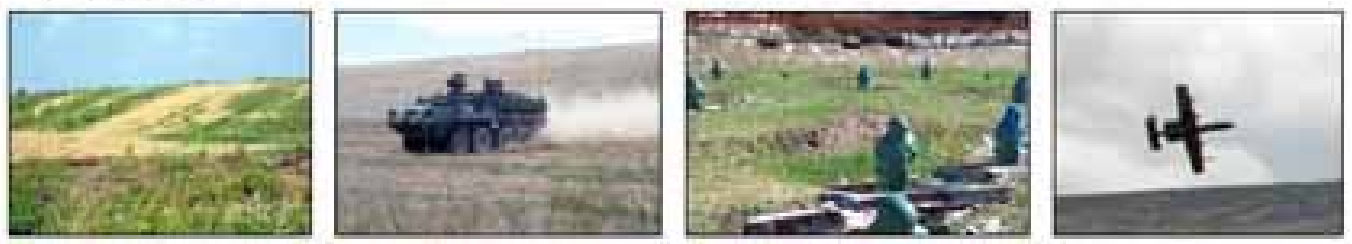

Figure 2. Factors affecting revegetation; different types of ecosystems, land use, and soil type require different types of vegetation.

These guidelines are formatted to answer questions about commonly reseeded areas. Section 2 contains information that may be useful in the overall planning process including site-specific needs, additional resources available to revegetation projects, requirements and funding, seed sources and quality, and other resources available to supplement the material in this guide.

Section 3 helps land managers select the proper seed mixtures based on the following criteria:

Ecosystem type - Climate sections in the guidelines are based on annual precipitation amounts and primary vegetation type. See Section 3. 1

Soil type - In these guidelines, the soil is described as one of two broad textural classifications: sand and silt/ clay. See Section 3.2.

Land use - We have divided training lands into two broad categories of light/moderate use and severe/ heavy use. We also include a third category of generally light use where low-growing vegetation is required, such as roadsides, small-arms ranges, and military operations in urban training (MOUT) sites. See Section 3.3.

Mixture type - Depending on the vegetation goals, we recommend introduced-species mixtures, native-species mixtures, or ecological- 
bridge mixtures, which combine introduced and native species to ultimately provide a native stand. See Section 3.4.

There are many other small, locally unique areas or applications at individual facilities that are outside the scope of these guidelines. These include development and protection of threatened and endangered species (TE) habitats that require plant materials not commonly used in land restoration, relocation of TE or other at-risk plants, and phytoremediation or phytostabilization of contaminated lands. Although restoration is outside the scope of these guidelines, land managers may find the guide useful for planning the restoration process. 


\section{Overall Planning Guidelines and Resources}

This section contains information helpful in the overall planning for a revegetation project. It includes regulations and funding, several aspects of revegetation projects that are not covered in detail in this guide, and additional resources for the land manager.

\subsection{Requirements and Funding}

The first step in the planning process for plant selection should begin with a review of the Sikes Act (16 U.S.C. 670 et seq.) and the Integrated Natural Resources Management Plan (INRMP) planning process. The Sikes Act requires the Secretary of Defense to carry out a program providing for the conservation and rehabilitation of natural resources in support of the military mission on public lands set aside for military activities. DoD installations must develop an Integrated Natural Resource Management Plan (INRMP) to implement this program. INRMPs are comprehensive plans coordinated between an installation, the U.S. Fish and Wildlife Service, and the state, and are the means by which installation natural resource programs are funded and implemented. In addition, Executive Order 13112 requires Federal agencies to prevent the introduction of invasive species, control existing invasive populations in a cost-effective and environmentally sound manner, and whenever possible restore native species and habitat conditions in ecosystems that have been invaded.

Conventional procurement methods as well as cooperative agreements in accordance with the Federal Grant and Cooperative Agreements Act (31 U.S.C. 6301-6308) and the Sikes Act may be used to accomplish work identified in installation INRMPs. In accordance with the Sikes Act, priority shall be given in contracting for the procurement of INRMP implementation and enforcement services with federal and state agencies having responsibility for the conservation or management of fish and wildlife (Section $101(\mathrm{~d})(2)$ ).

An explanation of the Sikes Act as amended through 2003 may be found at http://www.fws.gov/habitatconservation/2004SikesAct\%20NMFWA.pdf

Links to additional information and guidance on the Sikes Act are at 
https://www.denix.osd.mil/portal/page/portal/denix/environment/NR/conservation/Metrics

Links to information on the INRMP process are at

https://www.denix.osd.mil/portal/page/portal/denix/environment/NR/conservation/INRMP

Information about Executive Order 13112 may be found at

http://www.invasivespeciesinfo.gov/laws/execorder.shtml

\subsection{Preliminary Questions for Site-specific Planning}

Several questions regarding the type and intensity of use of the site should be considered when planning a seeding operation to develop a vegetated landscape. Answers to the following questions will facilitate the use of the guidelines in Section 3.

\section{What are your land management goals?}

Consider the types of vegetation (grasses, legumes, forbs), maximum plant height desired, and the percent ground cover needed for management goals such as habitat for a TE species, grazing by wildlife and/ or domestic livestock, and recreational activities.

\section{What future level (severe, moderate, or light) of land use or training do you expect?}

This question is important in selecting the species for revegetation. If training causes severe vegetation damage, more aggressive species in terms of rapid establishment and spreadability will be required to meet management goals of adequate ground cover.

\section{Is revegetation necessary?}

Are there a sufficient number of desirable plants present? If the future training load on this piece of property is low and, if training exercises are deferred on this site for an appropriate period, reseeding may not be required. A resting period may allow the existing vegetation to recover. See Section 2.6 below for more information.

\section{What are the site-specific plant establishment constraints?}

What are the major environmental considerations on the site: soil type, slope and aspect, and amount and seasonal distribution of annual precipitation? These questions are important to plant selection as described in Section 3. 


\section{What desirable plant species are already on the site?}

Conducting a quick vegetative survey will give a good indication of which desirable plant species are best adapted to the site. This information can then be correlated to the level and types of previous training events to determine the more resilient plant species present at the site. Use these species to refine the seeding mixture you select in Section 3.

\section{Which, if any, invasive plant species are present?}

The species and frequency of invasive weeds will affect revegetation strategies on training lands. If the invasive weeds, such as cheatgrass, are at high frequencies, more aggressive revegetation species will be needed to compete with these invasive plants. Ecological-bridge seed mixtures, which include both native and introduced species, can be used to eliminate the invasive weeds and eventually establish the desired native species.

\subsection{Some Plant Physiological Characteristics Important to Military Training Lands}

The morphological characteristics of the plants that are important for military land managers to consider are described in the Plant Description Sheets in Appendix B; Appendix A provides a summary of characteristics of selected grasses. As you begin to plan and select a seed mixture for your revegetation project, decide which of the following characteristics may be important on your site:

Low-growing vegetation - This is a desirable characteristic for several reasons, but the three most popular are improved line of sight, low flammability, and lower maintenance costs. Examples: introduced species such as crested wheatgrass and hard or sheep fescue (see Table 4).

Spreadability - To control soil erosion and reduce reseeding costs, it is desirable to include in the seed mixture one or more grasses or legumes that can spread into damaged areas. A good example is the native species western wheatgrass, which has aggressive rhizomes.

Habitat development - This characteristic is usually selected for a particular purpose such as establishing an endangered species or managing game lands. Plant materials will consist largely of a mixture 
of native species. 'FirstStrike' slender wheatgrass is a native species that establishes rapidly.

Dust control - This usually includes using vegetation for dust capture; tall vegetation is usually helpful. Examples of plants to include in the mixture are the native species basin wildrye and the introduced species tall or intermediate wheatgrass.

Rapid establishment - The ability of a seedling to establish and survive on dry disturbed sites is critical. Examples of species to include in mixtures include slender wheatgrass, crested wheatgrass, and Siberian wheatgrass.

\subsection{GIS Maps}

Selected sites can be identified, measured, and described with Geographic Information System (GIS) layers or the maps made from them. Such maps can be important planning tools to determine significant physical characteristics of the site. These maps could include information on soils, aspect, past and future training events, location of endangered species and other encroachment issues, and other things important to managing a particular military installation. GIS could also be used to assist in determining extent of damage, location of previously seeded areas, and size of areas to be planted (useful when determining amount of seed to be purchased).

\subsection{Planting Techniques}

Seed quality, seedbed preparation, and time of seeding are all important in plant establishment. The importance of these factors has been described in detail in many publications and is covered briefly here. Other sources of information in the Intermountain West are publications by J ensen et al. (2001) and Monsen et al. (2004).

\section{Seedbed preparation}

Cultural techniques for seedbed preparation on dryland seedings are well established. Military lands, where water for plant establishment and growth is limited, are not usually tilled, fertilized, or amended to improve their physical and chemical condition. Disking usually provides adequate soil preparation for all the types of lands considered in this planting guide. 
Herbicides for weed control are commonly used when establishing new seedings. Weedy annual broadleaf and grass species develop rapidly and compete strongly for available soil water and nutrients with slower maturing perennial grasses, legumes, and forbs. Care should be taken when using herbicides. For example, some herbicide applications prior to seeding for broadleaf weed control in grasses will either injure existing legumes or forbs or the establishment of young grasses. This guide is not intended to provide adequate information for application of herbicides. Before using any herbicides, read carefully and observe all directions, precautionary statements, and other information appearing on the appropriate EPA registered product label.

\section{Seed Quality}

Planting high-quality seed is important. Seed of some species is of poor quality or highly dormant, which must be considered when planting.

The quality of the seed should be printed on the seed label attached to each seed container you purchased. An analysis label as described by J ensen et al. (2001) includes the following:

$\begin{array}{ll}\text { Kind: Basin Wildrye } & \text { Origin: Utah } \\ \text { Variety: Magnar (VNS) } & \text { Lot No.: MBW-0016 } \\ \text { Purity: } 95.46 \% & \text { Cert. No.: (G-2090) } \\ \text { Inert: } 4.15 \% & \text { Germination: 95\% (TZ) } \\ \text { Other Crop: } 0.38 \% & \text { Dormant/ Hard Seed: 0.00\% } \\ \text { Weed Seed: } 0.11 \% & \text { Total Viability: (95\%) } \\ \text { Noxious Weeds: } 0.00 \% & \text { Test Date: } 17 \text { Oct 2000 }\end{array}$

For named cultivars, we recommend purchasing certified seed. With certified seed, you are assured that the seed in the bag is the variety it is claimed to be.

\section{Time of Seeding}

The most optimum seeding times vary with plant species and ecosystem. For specific planting times see J ensen et al. (2001) or review the plant guides available through the USDA-Natural Resources Conservation Service (NRCS) PLANTS Database web site http://plants.usda.gov/. 


\subsection{When is Reseeding Necessary?}

The need to reseed can be determined by an estimated guess on the amount of desirable species present. The guidelines in Table 1 are based on the Idaho NRCS Technical Note No. 10 "Pasture and Range Seedings Planning-Installation-Evaluation-Management" (page 15). If the density of the desired plants fall below the ranges given in the table, it may be desirable to reseed; note that plant densities will vary based on climate and soil quality.

Table 1. Plant density guide.

\begin{tabular}{|c|c|c|}
\hline $\begin{array}{l}\text { Mean Annual } \\
\text { Precipitation }\end{array}$ & Ecological Site & $\begin{array}{l}\text { Target Density } \\
\text { (plants/sq. ft.) }\end{array}$ \\
\hline $22 "+$ & Loamy 3.0 - 5.0 Shallow, Gravelly, Stony, Eroded, etc. & $2.0-4.0$ \\
\hline $16 "-22 "$ & Loamy 2.0 - 4.0 Shallow, Gravelly, Stony, Eroded, etc. & $1.0-3.0$ \\
\hline $12 "-16 "$ & Loamy 1.0 - 3.0 Shallow, Gravelly, Stony, Eroded, etc. & $0.8-2.0$ \\
\hline 10"-12" & Loamy 0.7 - 2.0 Shallow, Gravelly, Stony, Eroded, etc. & $0.5-2.0$ \\
\hline$<10^{\prime \prime}$ & $\begin{array}{l}\text { Loamy } 0.5-2.0 \text { Shallow, Gravelly, Saline, Calcare- } \\
\text { ous, etc. }\end{array}$ & $0.3-2.0$ \\
\hline
\end{tabular}

\subsection{Source Materials}

These guidelines were developed with input from our research and from existing planting guidelines. The new research results come from our 10year research and demonstration program as described in Section 1 of this guide. The planting guideline reference materials we used have strengths related to the various phases of military land revegetation; these references are:

J ensen, K.B., W.H. Horton, R. Reed, R. Whitesides (2001) Intermountain planting guide. Utah State University Publications, Logan, UT. This guide contains information on plant establishment on rangelands and divides the intermountain region into four ecosystems with various precipitation amounts in each.

Monsen, S.B., R. Stevens, R. Shaw, L. Nancy (2004) Restoring western ranges and wildlands. Gen. Tech. Rep. RMRS-GTR-136-volumes1-3. Fort Collins, CO: U.S. Department of Agriculture, Forest Service, Rocky Mountain Research Station. Three volumes describe the many phases of land revegetation in detail. It contains descriptions 
of the land preparation before seeding and descriptions of grasses, shrubs, and forbs.

Palazzo, A.J ., L. Gatto, and W. Woodson (1994) Guidelines for managing vegetation on earth-covered magazines within the U.S. Army Materiel Command. CRREL Report 94-6, Cold Regions Research and Engineering Laboratory, Hanover, $\mathrm{NH}$. This document was written for military land managers revegetating ammunition storage bunkers; it describes the planning process that military land managers can use.

USDA-ARS Web Site http://plants.usda.gov and Ogle et al. (2008a) provide a general description of each plant species recommended in this guide. Appendix B of this document summarizes relevant characteristics of the plants most relevant to military land revegetation applications. These characteristics include maximum plant height, tolerance to fire, and other factors of interest to military land managers. Also, Ogle et al. (2008b) reviews basic questions before beginning any land improvement by seeding begins for pasture and range improvement seedings.

Additional information on invasive weeds by state can be found at http://www.fs.fed.us/rm/boise/research/shrub/links.shtml. 


\section{Selecting the Seed Mixture}

The tables in this section recommend plant species to include in seed mixtures for various locations in the Intermountain West Region of the United States. Tables 2-4 provide a key to selecting the most adaptable seed mixture for the soil type and level of land use; the goal is to fit the plants to the land-use goals of the site. To benefit most from these tables, we recommend you follow a four-step process in selecting seeds:

1. Identify the location, precipitation, and ecosystem:

- Sagebrush and pinyon juniper

- Big sagebrush-grass

- Wyoming big sagebrush

- Black greasewood, saltbush

- Shadscale, saltbush/ winterfat

NOTE: Because of specific revegetation requirements, MOUT sites, small-arms ranges, airports, etc. are considered separately from the ecosystem categories

2. Describe the soil texture

- Silt/clay

- Sand

3. Identify the training level

- Light/medium

- Severe

- MOUT sites, airfields, roadsides, or small-arms range

4. Select and refine the seed mixture.

- All native $(\mathrm{N})$ mixes

- All introduced (or naturalized) (I) mixes

- Ecological bridge (E) mixes containing both introduced and native species

Each step is described in detail below. 


\subsection{Identify Ecosystem and Annual Precipitation}

We use five broad ecosystems that are most likely to be found on installations in the Intermountain West.

Upland ecosystems (see Table 2)

- Sagebrush and pinyon juniper grass; 14-18 in. precipitation

- Big sagebrush, grass; 12-16 in. precipitation

Semi-desert ecosystems (see Table 3)

- Wyoming big sagebrush; 10-12 in. precipitation

- Black greasewood and saltbush; 8-10 in. precipitation

- Shadscale, saltbush/ winterfat; 8-10 in. precipitation

Further information on ecosystems can be found in Chapter 2 of Monsen et al. (2004) and in Bailey's Ecosystem Guide

(http://www.ff.fed.us/land/ecosysmgmt/ecoreg1 home.html). While the amount of annual precipitation is important, it is also important to know when most precipitation occurs during the year for proper timing of seeding. The annual amount of precipitation and when it occurs is readily available from airports at many of the military bases. Local airports are also a good source of precipitation data.

\subsection{Describe the Soil Texture}

Soil texture is a measure of the proportions of sand, silt, and clay. This guide relates only to two broad textural classifications: silt/ clay or sand (Figure 3). Texture can be more accurately defined and may be important to consider since these soil properties are closely associated with water movement in the soil profile and the ability of the soil to retain water. The important consideration here is the adaptability of the plants to silt/ clay or sandy soils. Tables 2 and 3 include choices for silt/ clay or sandy soils within each ecosystem.

Soil surveys and associated maps produced primarily by the USDA-NRCS are a valuable tool in identifying information related to soil fertility, texture, drainage, and other soil characteristics. 


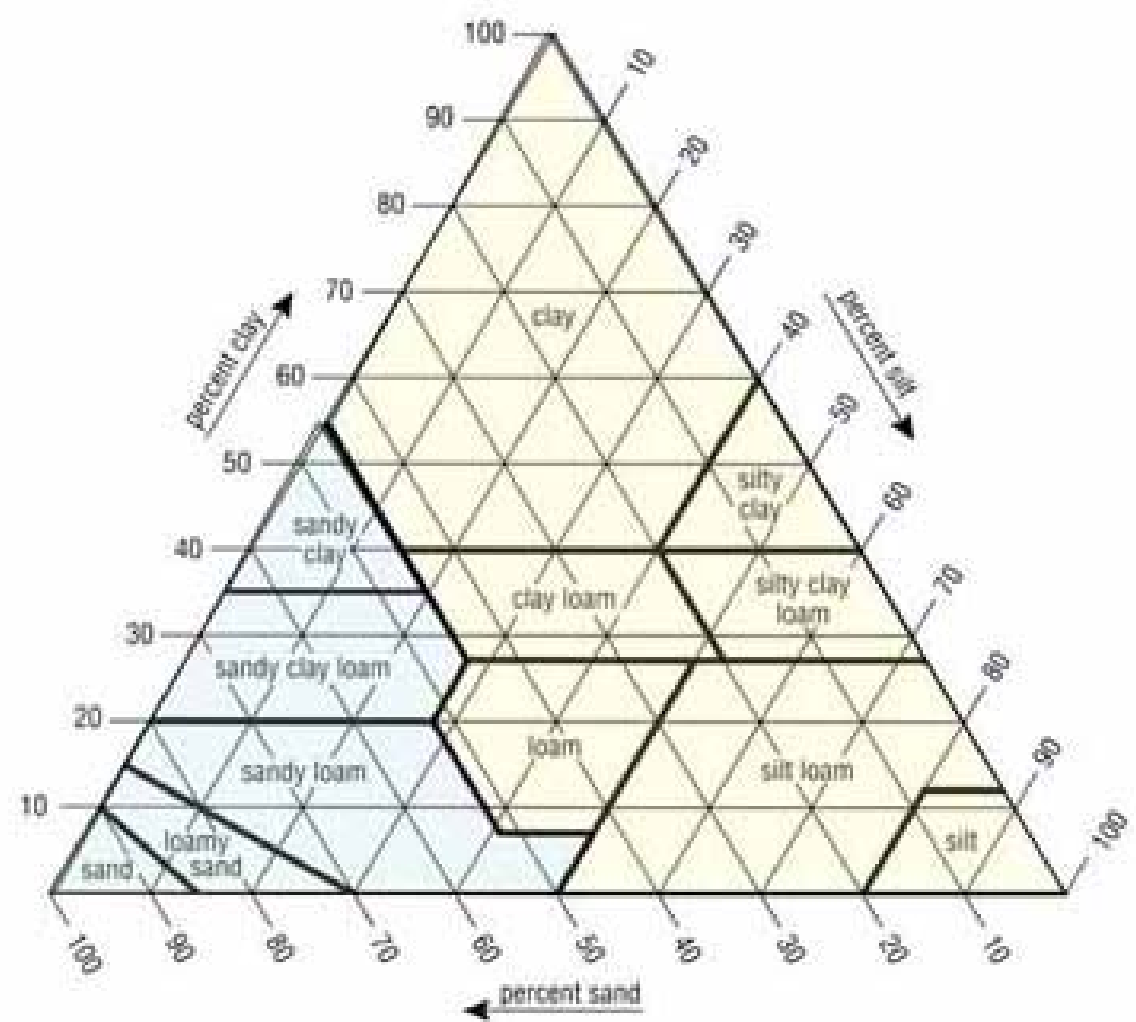

Figure 3. Soil texture classifications (from USDA-NRCS). The colored areas indicate the two broad classifications used in this guide: sand (blue) and silt/clay (yellow).

\subsection{Identify the Training Level or Land Use}

We have divided the land use into three categories, each requiring different types of seed mixtures. Here we describe these use categories and the criteria for selecting the most appropriate seed mixture for the site.

\section{Intensive land use on range and training areas}

Description of site - These are sites where equipment or people have largely depleted the vegetation, resulting in reduced ground cover (about less than $25 \%$ vegetative cover). These sites could include heavily used training areas and bivouac sites. Desirable vegetation is limited under intensive use, and invasive weeds are probably present.

Revegetation goals - The goals are usually to prevent soil erosion and stream sedimentation and to maintain topsoil that will support vegetation growth in the future. This type of site requires plants that can either establish rapidly or are resilient to disturbance and the encroachment of weedy species. 
Criteria or key words required from seed mixture - Rapid plant establishment, introduced species, soil conservation

Seed mixtures to consider - These sites will probably need to be reseeded often. Therefore, cost-effective, rapidly establishing plants are recommended. Components of the seed mixture often include introduced (naturalized) species, such as crested and Siberian wheatgrass, and easyto-establish natives, such as slender wheatgrass, which is a short-lived native perennial grass that does not normally persist more than 3 to 4 years. See Tables 2 and 3.

\section{Light and moderate land use on range and training areas}

Description of site - For this guide, we define moderately disturbed lands as those disturbed by either equipment or people and where less than $50 \%$ of the desirable vegetation cover has been destroyed; invasive weeds may be present. Light disturbance could be areas where less than $25 \%$ of the desirable vegetation is disturbed. The major difference in the two types of disturbance is the amount of recovery time required for the desirable plants to maintain their dominance within the plant community. The recovery time for the plants will differ among sites with the types of plants present (whether they are rhizomatous or seed producers) and annual rainfall amounts.

Revegetation goals - The goal is usually to establish native plants. In lightly used areas, the vegetation has time to establish. An ecologicalbridge mixture should be considered on moderately used lands and on lightly used lands. If invasive weeds are a problem, then it would be difficult to use only native plants and selected introduced (naturalized) species should be considered.

Seed mixtures to consider - These are excellent sites for native plants or an ecological-bridge seed mixture. An ecological-bridge seed mixture is more appropriate on dry sites and if invasive weeds are present. See Tables 2 and 3.

\section{MOUT sites, small-arms ranges, airfields, and roadsides}

Description of site - Although these sites vary considerably in land use, they all require low-growing vegetation to maintain lines of site, provide a low-maintenance lawn, or serve as a firebreak. Low-growing areas usually do not require reseeding after initial establishment. 
MOUT sites, airfields, and roadsides usually require low-growing grasses around buildings and must be resistant to drought and invasive weeds as well as tolerant of mowing.

Small-arms ranges usually include a level area and a sloping area. Vegetation on the level area must be low-growing similar to the MOUT site vegetation. On the slopes, the grasses should also be low growing but slope aspect must be considered. South-facing slopes will require plants that are more tolerant of high temperature and drought than north-facing slopes. Another important goal is to select plants that are not susceptible to uptake of metals and organic contaminants. For example, the fine fescues are reported to take up less zinc on a contaminated site than do some other grasses (Palazzo et al. 2003). Rapid establishment and plant spread by rhizome development is a high priority on the sloping soils to prevent soil erosion.

Revegetation goals - Existing vegetation on these sites is usually not under intensive use. The revegetation goal is to establish a low-growing, dense vegetative cover that will persist. Except on sloping areas, rapid establishment is not a high priority because these sites are not intensively used.

Seed mixtures to consider - Desired plant materials include all or a majority of low-growing species that are tolerant to close mowing or require only a single mowing in a season. Because low growth is the primary concern, we have not divided these recommendations into introduced, native, or ecological-bridge mixtures; chose those species that best meet the needs at your site. The recommendation is to mow these plants annually at the heading stage to remove seed stalks and reduce plant height. See Table 4.

\subsection{Select and Refine the Seed Mixture}

We recommend planting seed mixtures (grasses, legumes, and forbs) to enhance biological diversity. Tables 2 and 3 recommend appropriate plant species for mixes in each ecosystem, soil texture, and training level combination. X marks indicate if a particular species is recommended for use in one of three mix types: all natives $(\mathrm{N})$, all introduced or naturalized (I), or an ecological-bridge mixture (E) that combines native and introduced species. After you have developed the desired list of potential species, you must select the appropriate type of mix, following guidelines given below and in the preceding section on land-use types. You may 
further refine the mix choices by referring to the summary information in Appendix A and the individual plant descriptions in Appendix B.

We recommend three types of seed mixtures for their establishment and persistence under training in different conditions. Note that all three mixtures are not appropriate for all land-use categories considered. Introduced species are not usually recommended for lightly or moderately used lands to be compliant with Executive Order 13112, which requires control of invasive species and encourages the use native plants whenever possible. Under severe land use, natives are not recommended because the vegetation will be degraded frequently, and native seeds are usually more expensive, take longer to establish, and are not competitive with weedy species, especially on arid and semiarid sites.

Because the recommended mixtures may not be appropriate for all land uses within the broader land-use categories, you should also review the general morphological characteristics of the individual species (see Appendix B) in the mixtures to determine if their height or biomass production is appropriate for the lands being reseeded. An example is plant height, which is why we have a separate section for MOUT sites and firing points.

\section{Seed mixtures dominated by or entirely of introduced species (I)}

Introduced-species mixtures are mostly selected for lands that are intensively used and need to be reseeded often. They are the most costeffective and provide the most rapid establishment thereby minimizing the establishment and dominance of invasive weeds. Lands can usually be used again in one or two years after reseeding.

Best use. Intensively used land. Easy-to-establish natives, such as slender wheatgrass, may sometimes be added to these mixes.

Drawback. They do not provide a native plant stand and care should be taken to select species that are not overly aggressive and spread to other sites.

\section{Seed mixtures dominated by or entirely of native species (N)}

Seeding native mixtures helps comply with Executive Order 13112 that requires use of native plants whenever possible. These mixtures also 
provide low maintenance costs, habitat for threatened and endangered (TE) species, and good will with the public.

Best use. Lightly used lands.

Drawback. The seeds are more expensive and they are more difficult to establish, particularly on drier sites. A general rule is that between two to five years are required to fully establish native stands, and, consequently, invasive weeds can be a problem.

\section{Ecological-bridge mixtures (E)}

These diverse mixtures contain both introduced and native seeds, and they are formulated to provide a plant community of primarily native plants within five years. They are easier to establish than native-only mixtures, thus allowing the land to be used relatively soon for moderate training. Ecological-bridge mixtures work as well as introduced-species mixtures in controlling invasive weeds.

Best use. Moderately used to lightly used lands with invasive weed problems and drier lightly used lands.

Drawback. The major concern is selecting the right species to include in the mixture for the land to be revegetated. In these mixtures, the introduced species must establish rapidly to provide competition against invasive weeds and facilitate establishment of desired native species. The key to a successful ecological bridge mixture is to adjust the seed mixtures to give the natives a much bigger advantage while still reducing erosion and providing competition with weeds. 
Table 2. Suggested species to include in seed mixtures for rangeland plantings in upland ecosystems.

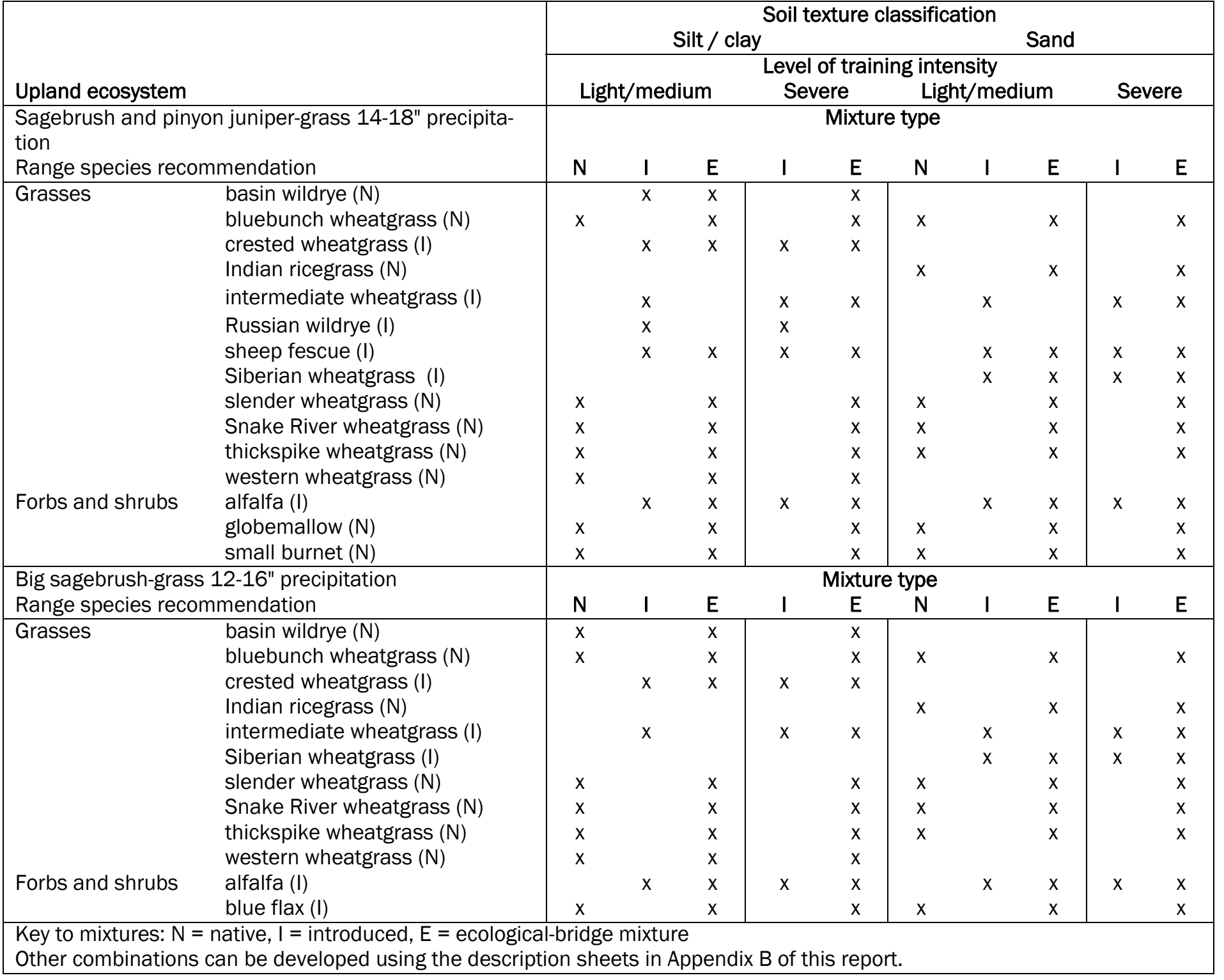


Table 3. Suggested species to include in seed mixtures for rangeland plantings in semi-desert ecosystems.

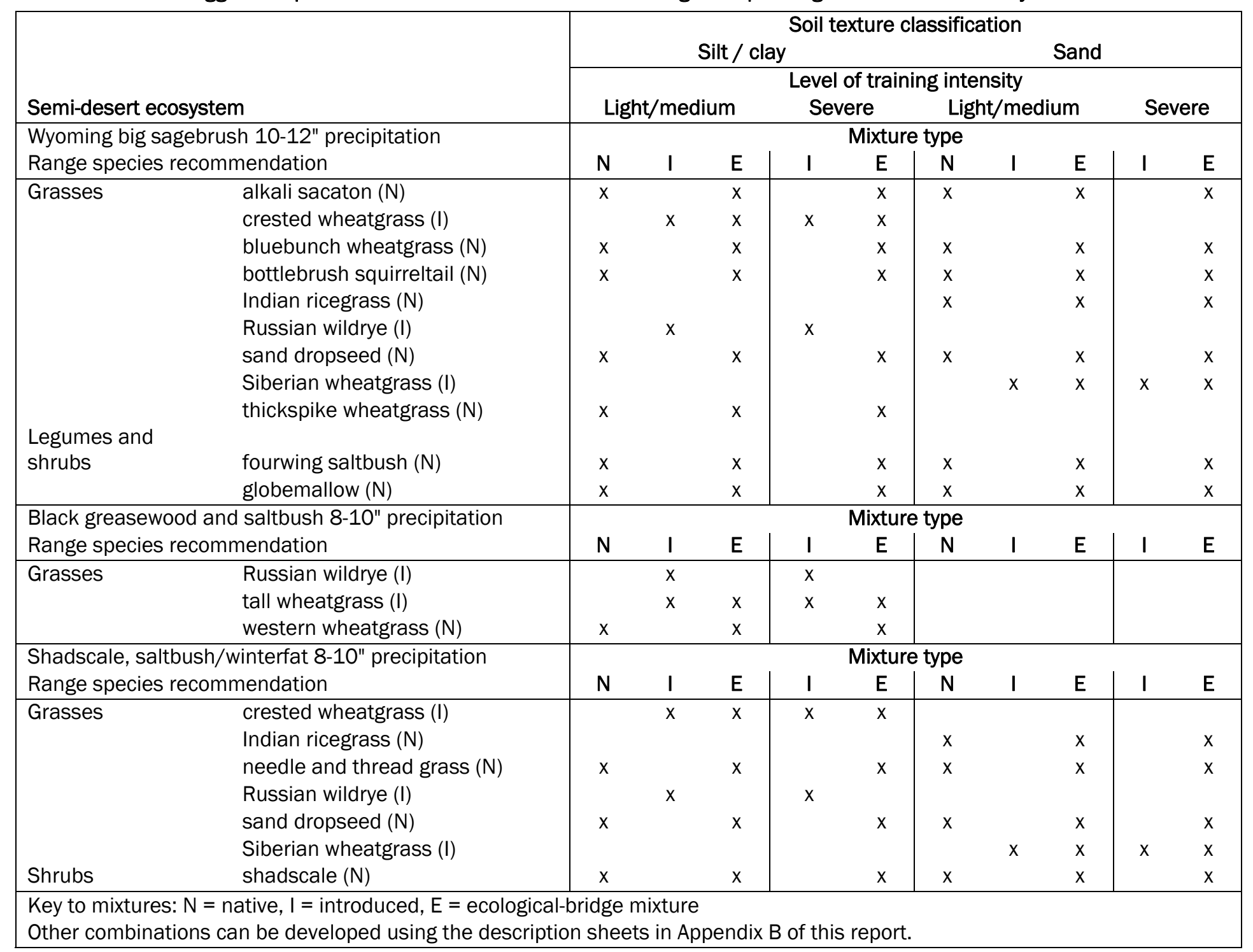


Table 4. Suggested low-growing grasses for military operations in urban training (MOUT) or small arms sites.

\begin{tabular}{|l|}
\hline Species \\
\hline Turf-type tall fescue $(\mathrm{I})$ \\
Turf-type crested wheatgrass (RoadCrest or Ephraim) $(\mathrm{I})$ \\
Sheep fescue $(\mathrm{I})$ \\
Western wheatgrass $(\mathrm{N})$ \\
Sodar thickspike (streambank) wheatgrass $(\mathrm{N})$ \\
Buffalo grass $(\mathrm{N})$ \\
\hline
\end{tabular}




\section{References}

Anderson, A.B., A.J . Palazzo, P.D. Ayers, and J .S. Fehmi (2005) Assessing the Impacts of Military Vehicular Traffic on Natural Areas. J ournal of Terramechanics, 42:143158.

Asay, K.H., N.J . Chatterton, K.B. J ensen, R. R-C. Wang, D.A. J ohnson, W.H. Horton, A.J . Palazzo, and S.A. Young (1997) Registration of 'CD-II' Crested Wheatgrass. Crop Science, 37:1023.

Asay, K.H., W.H. Horton, K.B. J ensen, and A.J . Palazzo (2001) Merits of native and introduced Triticeae grasses on semiarid rangelands. Canadian J ournal of Plant Science, 81: 45- 52.

Hu, Z-M., R. R.-C. Wang, S. R. Larson, A. J . Palazzo, K. H. Asay, and N. J . Chatterton (2001) Selection response of molecular markers associated with anthocyanin coloration and low-temperature growth traits in crested wheatgrass. Canadian J ournal of Plant Science, 81:665- 671.

Huff, D.R., and A.J . Palazzo (1998) Fine fescue species determination by laser flow cytometry. Crop Science, 38:445- 450.

Huff, D.R., J . Quinn, B. Higgins, and A.J . Palazzo (1998) RAPD variation among little bluestem [Schizachyrium scoparium (Michx.) Nash] populations from sites of high and low fertility in forest and grassland biomes. Molecular Ecology, 7:15911597.

Idaho NRCS Technical Note No. 10 "Pasture and Range Seedings Planning-InstallationEvaluation-Management".

J ensen, K.B., A. Palazzo, B.L. Waldron, J .G. Robins, B.S. Bushman, D.A. J ohnson, and D. Ogle (2009) 'Vavilov II', a new Siberian wheatgrass cultivar with improved persistence and establishment on rangelands. J . Plant Registrations 3:57-60.

J ensen, K.B., A.J . Palazzo, B.L. Waldron, and B.S. Bushman (2007) Registration of 'FirstStrike' slender wheatgrass. J ournal of Plant Registrations, 1: 24-25.

J ensen, K.B., K.H. Asay, D.A. J ohnson, S.R. Larson, B.L. Waldron, and A.J . Palazzo (2006) Registration of Bozoisky-II Russian wildrye. Crop Science, 46:986-987.

J ensen, K.B., W.H. Horton, R. Reed, and R. Whitesides (2001) Intermountain planting guide. Utah State University Publications, Logan, UT.

J ensen, K.B., K.H. Asay, D.A. J ohnson, W.H. Horton, A.J . Palazzo, and N.J . Chatterton (1998) Registration of RWR-Tetra-1 Tetraploid wildrye germplasm. Crop Science, 38:1405.

J ones, T.A., S.R. Larson, D.C. Nielson, S.A. Young, N.J . Chatterton, and A.J . Palazzo (2002) Registration of P-7 Bluebunch wheatgrass germplasm. Crop Science, 42: 1754- 1755. 
Larson, S.R., X. Wu, T.A. J ones, K.B. J ensen, N.J . Chatterton, B.L. Waldron, J .G. Robins, B.S. Bushman, and A.J . Palazzo (2006) Comparative mapping of growth habit, plant height, and flowering QTLs in two interspecific families of Leymus. Crop Science, 46:2526-2539.

Larson, S.R., A.J . Palazzo, and K.B. J ensen (2003) Maintenance of DNA variation within and among western wheatgrass cultivars and accessions. Crop Science, 43:394401.

Larson, S.R., B.L. Waldron, S. Monsen, L. St. J ohn, A.J . Palazzo, C.L. McCracken, R.D. Harrison (2001) Patterns AFLP variation in the Poa bluegrasses of western North America. Crop Science, 41:1300- 1305.

Larson, S.R., T.A. J ones, Z-M. Hu, A.J . Palazzo, and C.L. McCracken (2000) Genetic diversity of bluebunch wheatgrass cultivars and a multiple-origin polycross. Crop Science, 40:1142- 1147 (featured on the cover).

Monsen, S.B., R. Stevens, R. Shaw, L. Nancy (2004) Restoring western ranges and wildlands. Gen. Tech. Rep. RMRS-GTR-136-volumes-1-3. Fort Collins, CO: U.S. Department of Agriculture, Forest Service, Rocky Mountain Research Station.

Ogle, D., L. St. J ohn, J . Cornwell, M. Stannard, and L. Holzworth. 2008a. Grass, grasslike, forb, legume, and woody species for the Intermountain West. USDANatural Resources Conservation Service. TN Plant Materials No. 24. J anuary 2008.

Ogle, D., L. St. J ohn, J . Cornwell, M. Stannard, and L. Holzworth. 2008b. Pature and range seedings planning-installation-evaluation-management. USDA-Natural Resources Conservation Service. TN Plant Materials No. 10. J anuary 2008.

Palazzo, A.J ., K.B. J ensen, S.E. Hardy, T.J . Cary, K.B. J ensen, B.L. Waldron, and S.R. Larson (in prep.) Implementation and Commercialization of New Germplasms for Use on Military Ranges. Cost and Performance Report Number SI-0401. Environmental Security Technology Certification Program (ESTCP). Washington DC.

Palazzo, A.J . and S.E. Hardy (1998) Department of Defense evaluates genetic diversity on military training lands and breeds new plants for Army training grounds.

Diversity, 14:28- 30.

Palazzo, A.J ., S.E. Hardy, and K.B. J ensen (2003) Improved native grasses and establishment methods for use on military training lands. ERDC-CRREL Report TR-03-20, Cold Regions Research and Engineering Laboratory, Hanover, NH. (also available at http://www.estcp.org/viewfile.cfm?Doc=CS\%2D1103\%2DFR\%2D01\%2Epdf)

Palazzo, A.J., K.B. J ensen, B.L. Waldron, and T.J . Cary (2005) Effects of Tank Tracking on Range Grasses. J ournal of Terramechanics, 42:177-191.

Palazzo A.J ., T.J . Cary, S.E. Hardy, and C.R. Lee (2003) Root growth and metal uptake in four grasses grown on zinc-contaminated soil. J ournal of Environmental Quality, 32:834-840. 
Palazzo, A.J ., L. Gatto, and W. Woodson (1994) Guidelines for managing vegetation on earth-covered magazines within the U.S. Army Materiel Command. CRREL Report 94-6, Cold Regions Research and Engineering Laboratory, Hanover, NH.

Waldron, B.L., T.A. Monaco, K.B. J ensen, R. D. Harrison, A.J . Palazzo and J .D. Kulbeth (2005) Coexistence of Native and Introduced Perennial Grasses following Simultaneous Seeding. Agronomy J ournal, 97:990-996.

Waldron, B.L., J .G. Robins, K.B. J ensen, A.J . Palazzo, T.J . Cary, and J.D. Berdahl (2006a) Population and environmental effects on seed production, germination, and seedling vigor in western wheatgrass (Pasopyrum smithii [Rydb.] A. Love). Crop Science, 46:2503-2508.

Waldron, B.L., K.B. J ensen, R.D. Harrison, A.J . Palazzo, and T.J . Cary (2006b) Registration of Yakima western yarrow germplasm (Source Identified). Crop Science, 46:488-489.

Waldron, B.L., S.R. Larson, J ensen, K.B., R.D. Harrison, A.J . Palazzo, and T.J Cary (2006c) Registration of Reliable Sandberg bluegrass germplasm (Selected Class). Crop Science, 46:487-488. 


\section{Appendix A. Summary of Plant Characteristics}

Table 5 below is from Monsen et al. (2004) and summarizes the characteristics of many of the grasses recommended in this guide. Note that the ratings for some characteristics may not agree exactly with information given in the plant description summaries in Appendix B. Actual plant performance will vary by site and soil type, and different agencies have differing opinions on some of the ratings.

The table uses the following rating system:

$$
\begin{aligned}
& 1=\text { Poor }- \text { difficult } \\
& 2=\text { Fair } \\
& 3=\text { Medium } \\
& 4=\text { Good } \\
& 5=\text { Excellent }- \text { easy } \\
& \text { A }=\text { Annual }- \text { reproduction from seed } \\
& \text { S }=\text { Reproduction from seed } \\
& \text { V }=\text { Reproduction vegetative (rhizomes or stolons) and from seed }
\end{aligned}
$$

The table uses the following abbreviations for vegetative types to which the species is adapted:
a. A = Aspen-conifer;
b. AW = Annual weed;
c. $\mathrm{BB}=$ Blackbrush;
d. $B G=$ Black greasewood;
e. $\mathrm{BS}=$ Basin big sagebrush;
f. $\mathrm{C}=$ Cheatgrass;
g. IS = Inland saltgrass;
h. JP =J uniper-pinyon;

i. $\quad \mathrm{MB}=$ Mountain brush;

j. $\quad \mathrm{MS}=$ Mountain big sagebrush;

p. WS $=$ Wyoming big sagebrush .

k. $\mathrm{PP}=$ Ponderosa pine;

l. $\mathrm{R}=$ Riparian;

$\mathrm{m}$. SA = Subalpine;

n. $\mathrm{SS}=$ Shadscale saltbush;

o. $\mathrm{WM}=$ Wet and semiwet meadows; 
Table 5. Characteristics of selected grasses (from Monsen et al. 2004)

\begin{tabular}{|c|c|c|c|c|c|c|c|c|c|c|c|c|c|c|c|c|c|}
\hline 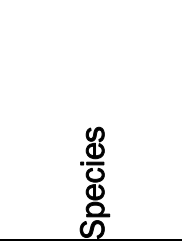 & 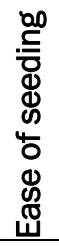 & 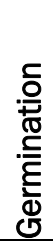 & 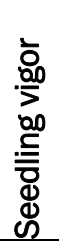 & 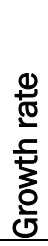 & 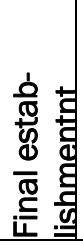 & 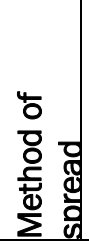 & 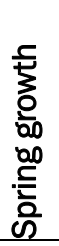 & 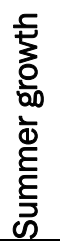 & 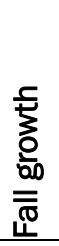 & 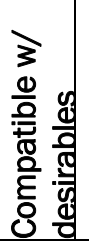 & 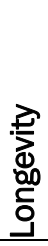 & 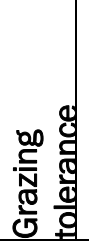 & 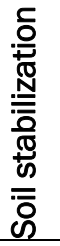 & $\begin{array}{l}\frac{0}{0} \\
\frac{1}{0} \\
\frac{0}{0} \\
\frac{0}{9} \\
\frac{0}{0} \\
\frac{0}{0} \\
\frac{5}{5}\end{array}$ & $\begin{array}{l}\frac{0}{0} \\
\frac{0}{0} \\
\frac{0}{0} \\
\frac{0}{0} \\
\frac{7}{8} \\
\frac{0}{4} \\
\end{array}$ & 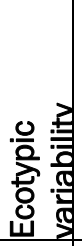 & 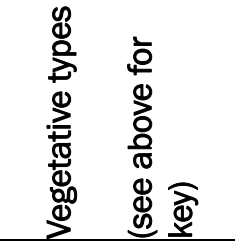 \\
\hline & \multicolumn{16}{|c|}{ ratings (see key above) - } & \multirow[b]{2}{*}{$\begin{array}{l}\text { MB, PP, JP, BS, } \\
\text { WS, SS, BB, C, } \\
\text { AW }\end{array}$} \\
\hline $\begin{array}{l}\text { Dropseed, } \\
\text { sand }\end{array}$ & 4 & 3 & 2 & 4 & 4 & S & 5 & 3 & 2 & 4 & 4 & 4 & 4 & 2 & 3 & 3 & \\
\hline $\begin{array}{l}\text { Fescue, } \\
\text { sheep }\end{array}$ & 5 & 5 & 4 & 4 & 4 & S & 5 & 3 & 2 & 3 & 4 & 4 & 4 & 2 & 2 & 5 & $\begin{array}{l}\text { SA, A, MB, PP, } \\
\text { MS }\end{array}$ \\
\hline $\begin{array}{l}\text { Needle-and- } \\
\text { thread }\end{array}$ & 3 & 3 & 4 & 3 & 5 & $\mathrm{~S}$ & 5 & 4 & 3 & 3 & 5 & 4 & 4 & 2 & 2 & 3 & $\begin{array}{l}\text { MB, PP, JP, BS, } \\
\text { WS, C, AW }\end{array}$ \\
\hline $\begin{array}{l}\text { Ricegrass, } \\
\text { Indian }\end{array}$ & 4 & 2 & 4 & 3 & 4 & $S$ & 5 & 2 & 2 & 4 & 5 & 4 & 4 & 2 & 5 & 4 & $\begin{array}{l}\mathrm{MB}, \mathrm{PP}, \mathrm{PJ}, \mathrm{MS} \\
\mathrm{BS}\end{array}$ \\
\hline $\begin{array}{l}\text { Sacaton, } \\
\text { alkali }\end{array}$ & 4 & 1 & 2 & 2 & 4 & V & 3 & 3 & 3 & 1 & 5 & 5 & 5 & 2 & 4 & 3 & $\begin{array}{l}\text { WM, BS, WS, SS, } \\
\text { BG, BB, IS, R }\end{array}$ \\
\hline $\begin{array}{l}\text { Wheatgrass, } \\
\text { bluebunch }\end{array}$ & 4 & 5 & 4 & 4 & 4 & $S$ & 5 & 3 & 4 & 4 & 5 & 4 & 4 & 3 & 5 & 5 & $\begin{array}{l}\text { MB, PP, JP, MS, } \\
B S, W S, C, A W\end{array}$ \\
\hline $\begin{array}{l}\text { Wheatgrass, } \\
\text { Siberian } \\
\text { crested }\end{array}$ & 5 & 5 & 4 & 4 & 4 & $S$ & 5 & 2 & 2 & 2 & 5 & 5 & 4 & 2 & 2 & 4 & $\begin{array}{l}\text { BS, WS, SS, BG, } \\
B B, I S, C, A W\end{array}$ \\
\hline $\begin{array}{l}\text { Wheatgrass, } \\
\text { slender }\end{array}$ & 5 & 4 & 5 & 4 & 4 & $\mathrm{~S}$ & 4 & 4 & 3 & 4 & 3 & 4 & 4 & 4 & 3 & 5 & $\begin{array}{l}\text { SA, A, MB, PP, } \\
\text { JP, MS }\end{array}$ \\
\hline $\begin{array}{l}\text { Wheatgrass, } \\
\text { Snake River }\end{array}$ & 5 & 5 & 5 & 4 & 4 & $\mathrm{~S}$ & 5 & 3 & 4 & 4 & 5 & 4 & 4 & 2 & 2 & 5 & $\begin{array}{l}\text { MB, PP, JP, MS, } \\
\text { BS, WS, C, AW }\end{array}$ \\
\hline $\begin{array}{l}\text { Wheatgrass, } \\
\text { standard } \\
\text { crested }\end{array}$ & 5 & 5 & 5 & 5 & 5 & $S$ & 5 & 2 & 3 & 1 & 5 & 5 & 5 & 3 & 2 & 4 & $\begin{array}{l}\text { MB, PP, JP, MS, } \\
B S, W S, S S, B G, \\
B B, C, A W\end{array}$ \\
\hline $\begin{array}{l}\text { Wheatgrass, } \\
\text { tall }\end{array}$ & 5 & 5 & 5 & 5 & 4 & $\mathrm{~S}$ & 4 & 3 & 3 & 2 & 4 & 4 & 4 & 3 & 5 & 4 & $\begin{array}{l}\text { MB, PP, JP, MS, } \\
\text { BS, WS, BG, IS, } \\
\text { R, C, AW }\end{array}$ \\
\hline $\begin{array}{l}\text { Wheatgrass, } \\
\text { thickspike }\end{array}$ & 5 & 4 & 4 & 4 & 3 & $\mathrm{~V}$ & 5 & 3 & 3 & 2 & 5 & 5 & 5 & 4 & 3 & 5 & $\begin{array}{l}\text { MB, PP, JP, MS, } \\
\text { BS }\end{array}$ \\
\hline $\begin{array}{l}\text { Wheatgrass, } \\
\text { western }\end{array}$ & 5 & 3 & 3 & 3 & 5 & $\mathrm{~V}$ & 5 & 3 & 3 & 3 & 5 & 5 & 5 & 4 & 3 & 5 & $\begin{array}{l}\text { MP, PP, JP, MS, } \\
\text { BS, WS, SS, BG, } \\
\text { R, C, AW }\end{array}$ \\
\hline $\begin{array}{l}\text { Wildrye, } \\
\text { Russian }\end{array}$ & 5 & 4 & 3 & 3 & 5 & $S$ & 5 & 4 & 4 & 4 & 5 & 5 & 4 & 2 & 2 & 4 & $\begin{array}{l}\text { MS, JP, MS, BS, } \\
\text { WS, SS, BG, BB, } \\
\text { IS, C, AW }\end{array}$ \\
\hline
\end{tabular}




\title{
Appendix B. Plant Description Sheets
}

\author{
In the description sheets below, blanks indicate that no information is \\ available. Fact sheets for most species are also available at \\ http://plants.usda.gov/.
}

\section{Common name}

Alkali sacaton

Basin wildrye

Blue flax and Lewis flax

Bluebunch wheatgrass

Bottlebrush squirreltail

Crested wheatgrass

Fourwing saltbush

Globemallow

Indian ricegrass

Intermediate wheatgrass

Needle-and-Thread grass

Russian wildrye

Sainfoin

Sandberg bluegrass

Shadscale saltbush

Sheep fescue

Siberian wheatgrass

Slender wheatgrass

Small burnet

Snake River wheatgrass

Tall wheatgrass

Thickspike wheatgrass

Western wheatgrass

Winterfat

\section{Scientific name}

Page

Sporobolus airoides

Leymus cinereus

Linum perenne and Linum lewisii 32

Pseudoroegneria spicata .......................................33

Elymus elymoides .........................................34

Agropyron cristatum, A. desertorum ………………….............35

Atriplex canescens ....................................... 37

Sphaeralcea ..........................................3 38

Achnatherum hymenoides ........................................39

Thinopyrum intermedium ........................................ 40

Hesperostipa comata ........................................ 41

Psathyrostachys juncea ...................................... 42

Onobrychis viciifolia ......................................... 43

Poa secunda .......................................... 44

Atriplex confertifolia ......................................... 45

Festuca ovina ........................................... 46

Agropyron fragile ........................................ 47

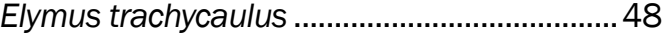

Sanguisorba minor .........................................49

Elymus wawawaiensis .........................................50

Thinopyrum ponticum ........................................ 51

Elymus lanceolatus ........................................52

Pascopyrum smithii ........................................53

Krascheninnikovia lanata ........................................54 


\begin{tabular}{|c|c|}
\hline & $\begin{array}{l}\text { Alkali sacaton is a tough perennial } 2 \text { to } 3.5 \text { feet } \\
\text { tall, growing in large bunches. The culms are } \\
\text { erect to spreading and range in height from } 50 \\
\text { to } 100 \mathrm{~cm} \text {. The blades are elongate, flat, soon } \\
\text { becoming involute, and usually less that } 4 \mathrm{~mm} \\
\text { wide. } \\
\text { Alkali sacaton grows on dry to moist sites with } \\
\text { sand or gravelly soil. This species is often found } \\
\text { growing on alkaline flats, prairies, and sandy } \\
\text { plateaus. It is common along drainage in desert } \\
\text { and semi-desert areas. }\end{array}$ \\
\hline & $\begin{array}{l}\text { Photo by R. Mohlenbrock USDA, NRCS, Wetland } \\
\text { Sciences Institute @ USDA-NRCS PLANTS Data- } \\
\text { base }\end{array}$ \\
\hline $\begin{array}{l}\text { Web site and fact sheet (for more infor- } \\
\text { mation): }\end{array}$ & http://plants.usda.gov/plantguide/pdf/cs_spai.pdf \\
\hline Mature height (ft): & 2 to $3 \mathrm{ft}$ \\
\hline Fire resistant (yes/no): & No \\
\hline Low growing (yes/no): & No \\
\hline Precipitation range (in.): & No information available \\
\hline Minimum root depth (in.): & No information available \\
\hline $\begin{array}{l}\text { Aggressiveness (fast, medium, slow } \\
\text { growth rate): }\end{array}$ & $\begin{array}{l}\text { Difficult to establish; on saline sites can be } \\
\text { competitive against annual weedy species }\end{array}$ \\
\hline Wear tolerance for maneuver areas: & $\begin{array}{l}\text { This grass increases on ranges that are closely } \\
\text { grazed during summer; therefore, may be resil- } \\
\text { ient to military training }\end{array}$ \\
\hline $\begin{array}{l}\text { Spread by rhizomes (may tolerate muni- } \\
\text { tions impacts): }\end{array}$ & No \\
\hline Ecological bridge suitability: & $\begin{array}{l}\text { Yes, but not with crested wheatgrass because } \\
\text { this species is not saline tolerant }\end{array}$ \\
\hline Additional notes: & \\
\hline
\end{tabular}




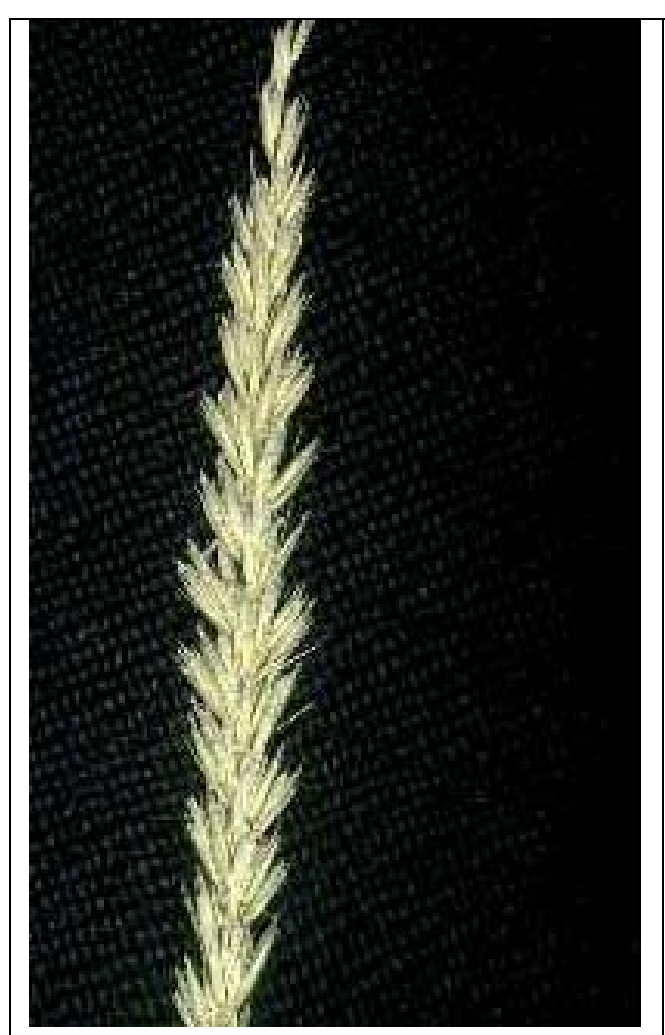

Basin wildrye is a large, coarse, robust, perennial bunchgrass. It is a long-lived cool season native with an extensive deep coarse fibrous root system. It has long leaf blades (15 to 25 inches) and flat wide (up to 3/4 inch) leaves with long pointed auricles. The reproductive stems are dense, stout, and strongly erect. Seed heads are 6 to 10 inches long. Basin wildrye clumps may reach 3 feet in diameter and 3 to 6 feet tall (10 feet under excellent soil and climate conditions). Growing points are 10 to 12 inches above the crown. Basin wildrye is well adapted to stabilizing disturbed soils. It does not compete well with aggressive introduced grasses during the establishment period, but it is very compatible with slower developing natives such as Snake River wheatgrass, bluebunch wheatgrass, thickspike wheatgrass, streambank wheatgrass, western wheatgrass, and needlegrass species. Basin wildrye's drought tolerance, combined with fibrous root system and fair seedling vigor, make it desirable for reclamation in areas receiving 8 to 20 inches annual precipitation. It is commonly used as a grass barrier for wind erosion or blowing snow control. It has also been planted on hilly cropland as a vegetative terrace for water erosion control.

Photo by Robert H. Mohlenbrock @ USDA-NRCS PLANTS Database

Web site and fact sheet (for more inforhttp://plants.usda.gov/plantguide/pdf/pg_leci4.pdf mation): 2 to $5 \mathrm{ft}$

Mature height (ft):
Fire resistant (yes/no):

Low growing (yes/no):

Precipitation range (in.): Tolerates wildfire if soil moisture is not too dry

Minimum root depth (in.):
8 to 20 in.

Aggressiveness (fast, medium, slow growth rate): Has deep fibrous root system

Fair seedling vigor; one of the first grasses to initiate spring growth; following the development of seed heads, it produces very little additional basal leaf growth; re-growth does not occur following seed production.

Wear tolerance for maneuver areas: Yes, with light training Spread by rhizomes (may tolerate muniReproduces primarily by seed and tillers tions impacts): Ecological bridge suitability: Yes Additional notes:

Establishes slowly, one of the first grasses to initiate spring growth; it is considered excellent cover habitat for small animals and birds, excellent nesting cover for upland birds, and excellent standing winter feed and cover for big game animals 
Blue flax and Lewis flax

\begin{tabular}{|c|c|}
\hline & $\begin{array}{l}\text { Linum perenne is introduced from Eurasia. In general, } \\
\text { flax is an annual or short-lived, semi-evergreen peren- } \\
\text { nial forb, sometimes semi-woody at base with attrac- } \\
\text { tive flowers ranging from white to blue to yellow to red } \\
\text { in color. Flax is common to the western United States. } \\
\text { Flax plants have many narrow, small, alternate (rarely } \\
\text { opposite), simple and entire leaves that are sessile } \\
\text { (lacking stalks) on the stems. The generally showy } \\
\text { flowers are borne in clusters. The flower is five-parted, } \\
\text { the fruit a capsule, and the seeds in most species are } \\
\text { slimy when wet. Cultivated flax is grown both for fiber } \\
\text { (flax) and for seed oil (linseed). }\end{array}$ \\
\hline 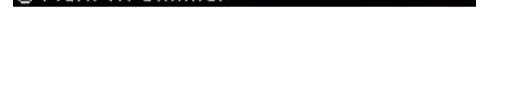 & $\begin{array}{l}\text { Photo by Mark W. Skinner @ USDA-NRCS PLANTS Da- } \\
\text { tabase }\end{array}$ \\
\hline $\begin{array}{l}\text { Web site and fact sheet for Linum } \\
\text { perenne (for more information): }\end{array}$ & http://plants.usda.gov/factsheet/pdf/fs_lipe2.pdf \\
\hline Mature height (ft): & No information available \\
\hline Fire resistant (yes/no): & $\begin{array}{l}\text { Yes, because the leaves and stems stay green with } \\
\text { relatively high moisture content during the fire season }\end{array}$ \\
\hline Low growing (yes/no): & Forb \\
\hline Precipitation range (in.): & 10 to $18+$ in. \\
\hline Minimum root depth (in.): & $6 \mathrm{in.}$ \\
\hline $\begin{array}{l}\text { Aggressiveness (fast, medium, } \\
\text { slow growth rate): }\end{array}$ & Medium \\
\hline $\begin{array}{l}\text { Wear tolerance for maneuver ar- } \\
\text { eas: }\end{array}$ & No information available \\
\hline $\begin{array}{l}\text { Spread by rhizomes (may tolerate } \\
\text { munitions impacts): }\end{array}$ & No \\
\hline Ecological bridge suitability: & $\begin{array}{l}\text { Blue flax can coexist with other species and add biodi- } \\
\text { versity to those plant communities }\end{array}$ \\
\hline Additional notes: & $\begin{array}{l}\text { There are several species of flax and they are noted } \\
\text { for their value in mixes for erosion control and beauti- } \\
\text { fication values. It is an annual or short-lived, semi- } \\
\text { evergreen perennial forb. }\end{array}$ \\
\hline
\end{tabular}

\section{Linum perenne and Linum lewisii}




\section{Bluebunch wheatgrass}

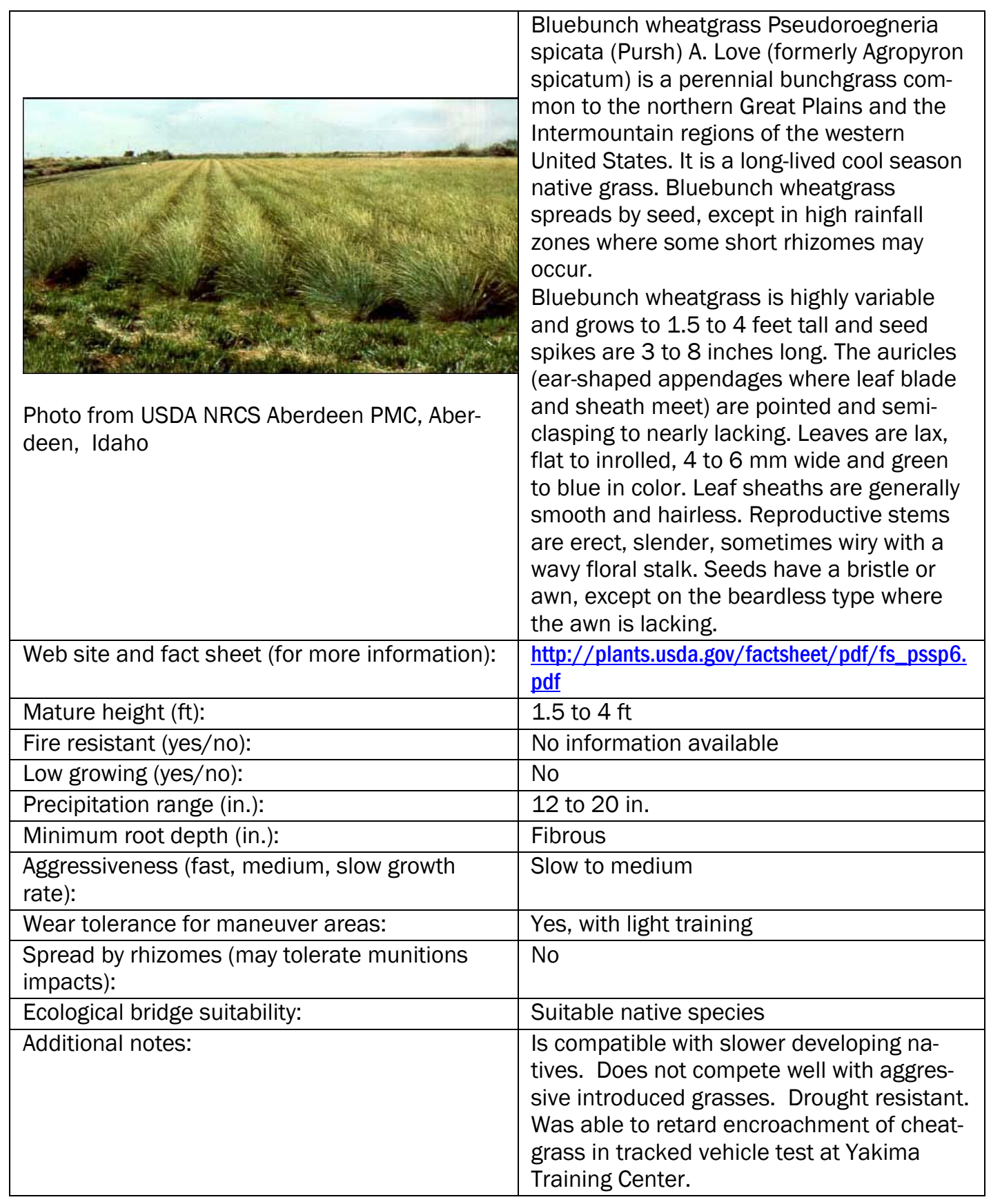

\section{Pseudoroegneria spicata}




\section{Bottlebrush squirreltail}

\section{Elymus elymoides}

\begin{tabular}{|c|c|}
\hline 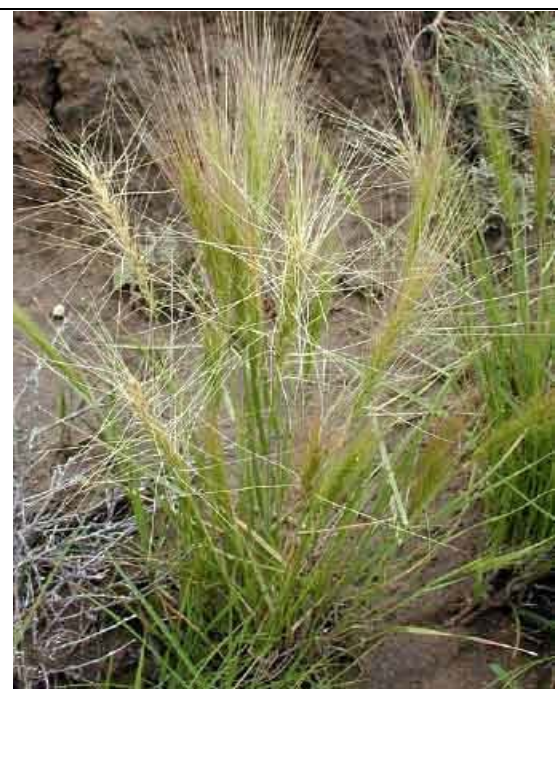 & $\begin{array}{l}\text { Squirreltail is a cool-season C-3 bunchgrass native } \\
\text { to the western United States. Foliage can be gla- } \\
\text { brous but is more often white hairy throughout. } \\
\text { Plants are short with culms erect to spreading. Leaf } \\
\text { blades are flat to involute, } 1 \text { to } 6 \mathrm{~mm} \text { ( } 0.04 \text { to } 0.24 \\
\text { inches) wide. The inflorescence is a spike from } 2 \text { to } \\
17 \mathrm{~cm} \text { ( } 0.8 \text { to } 6.7 \text { inches) long, not counting the } \\
\text { awns. Internodes of the inflorescence are from } 2 \text { to } \\
10 \mathrm{~mm} \text { (0.08 to } 0.40 \text { inches) long with the rachis } \\
\text { disarticulating regularly. At maturity, the spike can } \\
\text { be over } 12 \mathrm{~cm} \text { ( } 4.7 \text { inches) wide due to the widely } \\
\text { spreading awns. Awns are scabrous and may grow } \\
\text { from } 2 \text { to as much as } 10 \mathrm{~cm} \text { ( } 0.8 \text { to } 3.9 \text { inches) } \\
\text { long, these often becoming purple with maturity. } \\
\\
\text { Photo by Mike Haddock, Kansas State University @ } \\
\text { USDA-NRCS PLANTS Database }\end{array}$ \\
\hline $\begin{array}{l}\text { Web site and fact sheet (for more } \\
\text { information): }\end{array}$ & http://plants.usda.gov/plantguide/pdf/pg_elel5.pdf \\
\hline Mature height $(\mathrm{ft})$ : & 1 to $1.5 \mathrm{ft}$ \\
\hline Fire resistant (yes/no): & Yes \\
\hline Low growing (yes/no): & Yes \\
\hline Precipitation range (in.): & $\begin{array}{l}\text { Has various subspecies with different precipitation } \\
\text { limitations, } 10 \text { in. acceptable to most subspecies. }\end{array}$ \\
\hline Minimum root depth (in.): & Fibrous \\
\hline $\begin{array}{l}\text { Aggressiveness (fast, medium, slow } \\
\text { growth rate): }\end{array}$ & Slow \\
\hline Wear tolerance for maneuver areas: & Fair \\
\hline $\begin{array}{l}\text { Spread by rhizomes (may tolerate } \\
\text { munitions impacts): }\end{array}$ & No \\
\hline Ecological bridge suitability: & Yes \\
\hline Additional notes: & $\begin{array}{l}\text { Good choice for the ecological bridge seeding. } \\
\text { Short-lived perennial grass that can act as an early- } \\
\text { seral species by replacing annual weedy species } \\
\text { following fire. Competitive with the annual grasses } \\
\text { cheatgrass and medusahead; can persist on ranges } \\
\text { invaded by them. Ability to germinate and produce } \\
\text { roots at low temperatures permits it to establish in } \\
\text { annual grass-infested areas. Fairly tolerant of burn- } \\
\text { ing; ability to compete with cheatgrass may be fa- } \\
\text { vored by fire. }\end{array}$ \\
\hline
\end{tabular}


Crested wheatgrass

Agropyron cristatum, A. desertorum

\begin{tabular}{|c|c|}
\hline 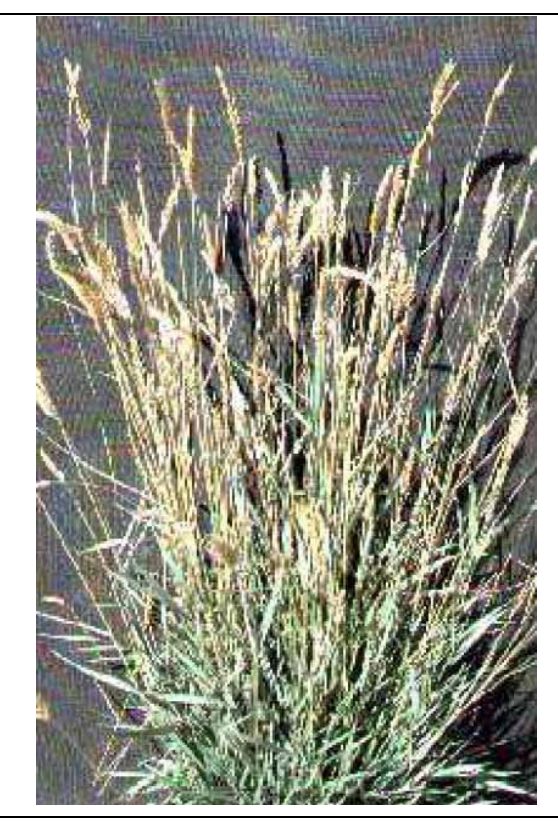 & $\begin{array}{l}\text { Crested wheatgrasses Agropyron cristatum, Agropy- } \\
\text { ron desertorum is perennial grasses commonly } \\
\text { seeded in the western United States. They are long- } \\
\text { lived, cool season, drought tolerant, introduced } \\
\text { grasses with extensive root systems. Cristatum type } \\
\text { crested wheatgrass grows from } 1 \text { to } 3 \text { feet tall and } \\
\text { seed spikes may be } 1.5 \text { to } 3 \text { inches long with a } \\
\text { short-broad shape that tapers at the tip. Flower } \\
\text { clusters within the spike are flattened and closely } \\
\text { overlapping. Each seed has a short awn. Stems are } \\
\text { leafy and erect, forming a dense tuft. Leaves are } \\
\text { flat, smooth below, slightly coarse above, and vary } \\
\text { in width from } 1 / 16 \text { to } 1 / 4 \text { inch. }\end{array}$ \\
\hline $\begin{array}{l}\text { Web site and fact sheet (for more } \\
\text { information): }\end{array}$ & http://plants.usda.gov/factsheet/pdf/fs_agcr.pdf \\
\hline Mature height (ft): & 1 to $3 \mathrm{ft}$ \\
\hline Fire resistant (yes/no): & No \\
\hline Low growing (yes/no): & Yes, if using cultivars 'Roadcrest' or 'Ephraim' \\
\hline Precipitation range (in.): & 10 to 16 in. \\
\hline Minimum root depth (in.): & Fibrous \\
\hline $\begin{array}{l}\text { Aggressiveness (fast, medium, slow } \\
\text { growth rate): }\end{array}$ & $\begin{array}{l}\text { Fast, if seeded at reduced rates less than } 2 \mathrm{lb} / \mathrm{A} \text { is } \\
\text { very compatible with other species. When seeded } \\
\text { at heavier rates may result in a closed community. }\end{array}$ \\
\hline Wear tolerance for maneuver areas: & Yes \\
\hline $\begin{array}{l}\text { Spread by rhizomes (may tolerate } \\
\text { munitions impacts): }\end{array}$ & $\begin{array}{l}\text { Only cultivars 'Roadcrest' and 'Ephraim' have rhi- } \\
\text { zomes }\end{array}$ \\
\hline Ecological bridge suitability: & Yes, at reduced seeding rates. \\
\hline Additional notes: & Formidable competitor with annual weeds. \\
\hline
\end{tabular}




\begin{tabular}{|l|l|}
\hline & $\begin{array}{l}\text { This perennial forb's striking feature is its scarlet flow- } \\
\text { ers. Five to ten long, narrow, tubular blossoms top } \\
\text { each of the numerous 2-ft high stems. Leaves are } \\
\text { tough, leathery, and deep green, arranged in pairs } \\
\text { along the coarse, purplish stems. }\end{array}$ \\
& \\
\hline $\begin{array}{l}\text { Web site and fact sheet (for more } \\
\text { information): }\end{array}$ & $\begin{array}{l}\text { Photo by Loren St. John @ USDA-NRCS PLANTS Data- } \\
\text { base }\end{array}$ \\
\hline Mature height (ft): & 2 to 5 ft \\
\hline Fire resistant (yes/no): & $\begin{array}{l}\text { Leaves stay green throughout the growing season. } \\
\text { Not tolerant of fire, but fire resistant due to leaves } \\
\text { staying green }\end{array}$ \\
\hline $\begin{array}{l}\text { Low growing (yes/no): } \\
\text { Precipitation range (in.): }\end{array}$ & Drought tolerant \\
\hline Minimum root depth (in.): & Fibrous, shallow root system \\
\hline $\begin{array}{l}\text { Aggressiveness (fast, medium, } \\
\text { slow growth rate): }\end{array}$ & No information available \\
\hline $\begin{array}{l}\text { Wear tolerance for maneuver ar- } \\
\text { eas: }\end{array}$ & No information available \\
\hline munitions impacts): & No \\
\hline Ecological bridge suitability: & No information available \\
\hline Additional notes: & $\begin{array}{l}\text { Common germplasm are Firecracker and Cedar. Can } \\
\text { plant with other native species. Other Penstemon spe- } \\
\text { cies: Bandera Rocky Mountain penstemon, Cedar } \\
\text { Palmer penstemon, Clearwater Venus penstemon, } \\
\text { Old Works fuzzytongue penstemon }\end{array}$ \\
\hline
\end{tabular}


Fourwing saltbush

\section{Atriplex canescens}

\begin{tabular}{|c|c|}
\hline 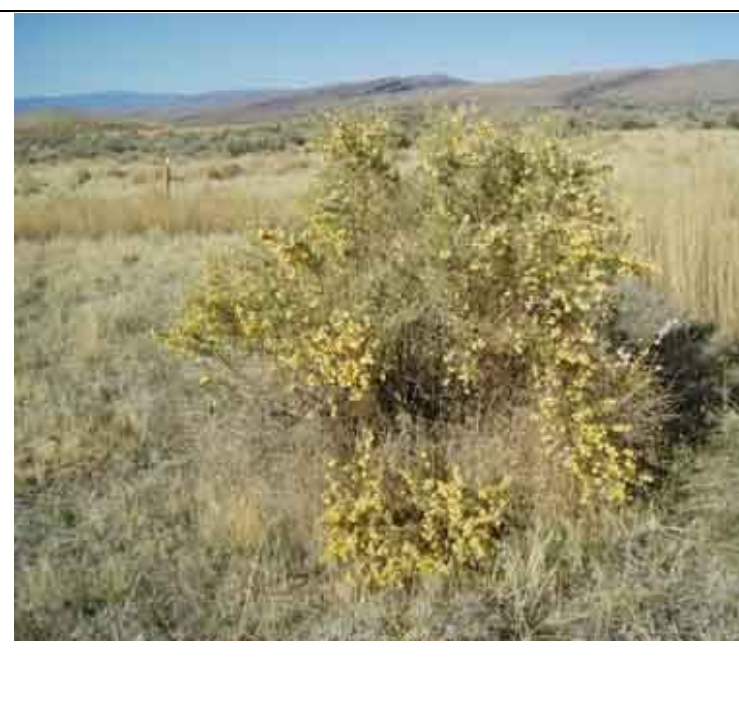 & $\begin{array}{l}\text { Atriplex canescens (Pursh) Nutt., four- } \\
\text { wing saltbush, is an evergreen, much } \\
\text { branched, gray shrub from } 2 \text { to } 6 \text { feet } \\
\text { tall occasionally reaching } 10 \text { feet tall. It } \\
\text { has stout, gray scurfy branches. Leaves } \\
\text { are alternate, linear-spatulate to nar- } \\
\text { rowly oblong, with } 1 / 2 \text { to } 2 \text { inches long } \\
\text { margins somewhat enrolled with a } \\
\text { dense, permanent scurf on both sides. } \\
\text { Male and female flowers are on sepa- } \\
\text { rate plants, male flowers in spikes form- } \\
\text { ing large panicles, female flowers in } \\
\text { spikes forming large, dense leafy, spike- } \\
\text { like panicles. Fruiting bracts have four, } \\
\text { free, flat, entire or fringed wings from } \\
\text { which the plant gets its name. } \\
\text { ERDC-CRREL photo }\end{array}$ \\
\hline Web site and fact sheet (for more information): & $\begin{array}{l}\text { http://plants.usda.gov/factsheet/pdf/fs_atc } \\
\text { a2.pdf }\end{array}$ \\
\hline Mature height (ft): & 2 to $6 \mathrm{ft}$ \\
\hline Fire resistant (yes/no): & No \\
\hline Low growing (yes/no): & No \\
\hline Precipitation range (in.): & 6 to 12 in. \\
\hline Minimum root depth (in.): & No information available \\
\hline Aggressiveness (fast, medium, slow growth rate): & No information available \\
\hline Wear tolerance for maneuver areas: & No information available \\
\hline $\begin{array}{l}\text { Spread by rhizomes (may tolerate munitions im- } \\
\text { pacts): }\end{array}$ & No information available \\
\hline Ecological bridge suitability: & $\begin{array}{l}\text { The plant has excellent potential for } \\
\text { plantings to promote native species }\end{array}$ \\
\hline Additional notes: & $\begin{array}{l}\text { Fourwing saltbush makes excellent low } \\
\text { screens, hedges, and barriers }\end{array}$ \\
\hline
\end{tabular}


Globemallow

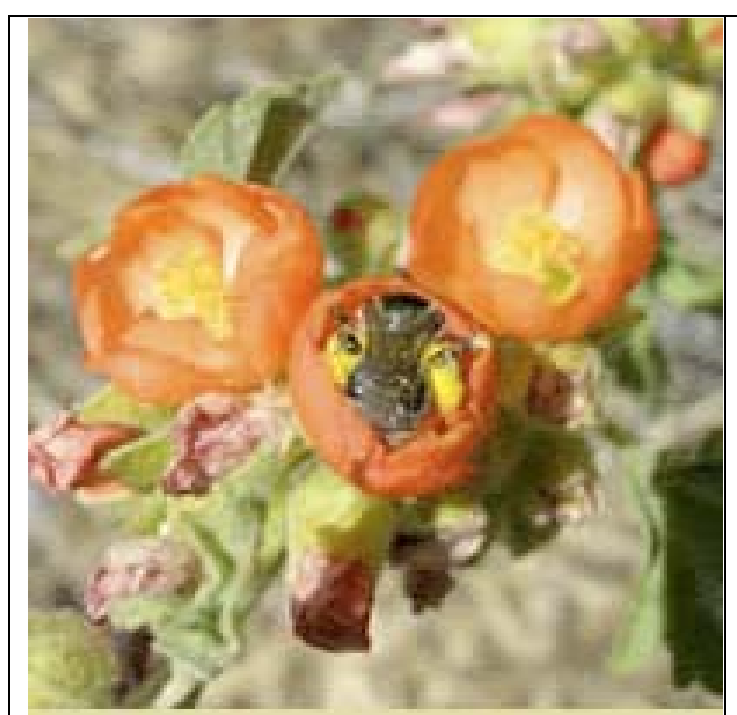

Web site and fact sheet (for more information):

\section{Sphaeralcea}

A grayish perennial herb, usually growing in clumps. Has a height of between 12 and 40 in. It is drought-resistant. During wet years it forms orange display flowers.

Photo by Vince Tepedino, USDA-ARS Bee Research Lab.

http://plants.usda.gov/java/profile?symbol=SPHA $\underline{E}$

0.5 to $1.5 \mathrm{ft}$

No information available

Forb

7 to 14 in.

No information available

Slow due to hard seed coat

No

Yes

No information available

A forb. Can be used to suppress cheatgrass

and other annuals. 
Indian ricegrass

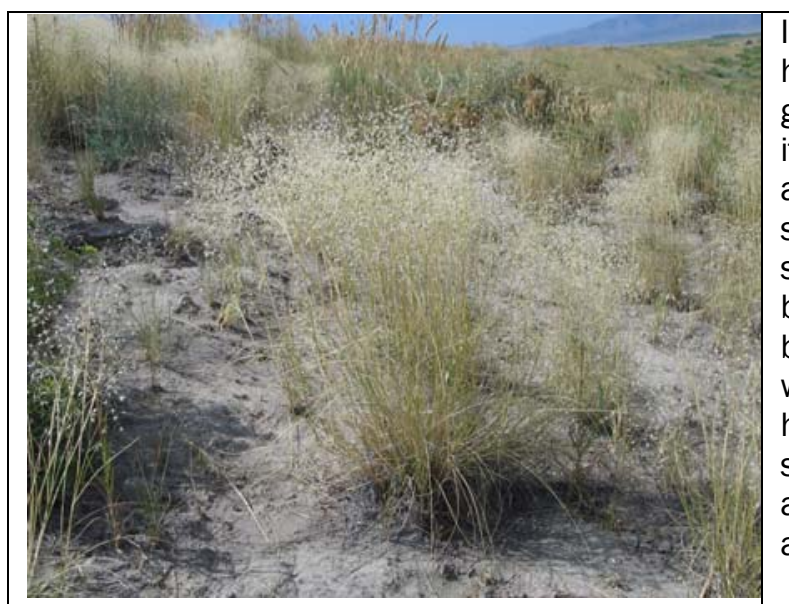

Indian ricegrass is 8 to 30 inches tall. It has many tightly rolled, slender leaves, growing from the base of the bunch giving it a slightly wiry appearance. The ligule is about 6-mm long and acute. It has a wide spreading panicle inflorescence with a single flower at the end of each hair-like branch. Seeds are round to elongated, black or brown, and generally covered with a fringe of short, dense, white callus hairs. Indian ricegrass has fair to good seedling vigor. Seed of most accessions are very slow to germinate due a thick hull and embryo dormancy.

Photo by: Dan Ogle, Plant Materials Specialist, USDA, NRCS, Idaho

Web site and fact sheet (for more information):

http://plants.usda.gov/plantguide/pdf/pg_ach y.pdf

\begin{tabular}{l|}
\hline Mature height (ft): \\
\hline Fire resistant (yes/no): \\
\hline Low growing (yes/no): \\
\hline Precipitation range (in.): \\
\hline Minimum root depth (in.): \\
\hline Aggressiveness (fast, medium, slow growth rate): \\
\hline Wear tolerance for maneuver areas: \\
\hline $\begin{array}{l}\text { Spread by rhizomes (may tolerate munitions } \\
\text { impacts): }\end{array}$
\end{tabular}

Ecological bridge suitability:

Well adapted to stabilization of disturbed sandy soils in mixes with other species

Additional notes:

Used for stabilizing sites susceptible to wind erosion. Does not compete well with aggressive introduced grasses during the establishment period. Short-lived deep, fibrous root system. Most common grasses on semiarid and arid lands of the West. Most drought-tolerant native range grasses. Dominant or associated species in creosote bush, salt desert, big sagebrush, black sagebrush, pinyon-juniper, ponderosa pine, and mixed-grass prairie communities. Fire tolerant when dormant. Early successional species. Will not persist in clay or loamy soils. Best suited for sandy sites. 
Intermediate wheatgrass

\begin{tabular}{|c|c|}
\hline $\begin{array}{l}\text { Photo from Big Flats PMC, Big Flats, NY @ } \\
\text { USDA-NRCS PLANTS Database }\end{array}$ & $\begin{array}{l}\text { Intermediate wheatgrass is an introduced } \\
\text { perennial grass native to Europe and Asia. } \\
\text { Intermediate wheatgrass' vegetative struc- } \\
\text { tures are for the most part smooth, but } \\
\text { may have a fringe of hairs on the leaf mar- } \\
\text { gins. Intermediate wheatgrass grows to } 3 \\
\text { to } 4 \text { feet tall. It is a long-lived, cool season } \\
\text { grass with short rhizomes and a deep } \\
\text { feeding root system. The seed spikes may } \\
\text { be up to } 4 \text { to } 8 \text { inches long. Leaves are } 4 \\
\text { to } 8 \mathrm{~mm} \text { wide and green to blue-green in } \\
\text { color and sometimes drooping. The florets } \\
\text { are usually fewer than seven. Intermediate } \\
\text { and pubescent wheatgrass readily cross } \\
\text { and commercial seed often contains both } \\
\text { types. }\end{array}$ \\
\hline Web site and fact sheet (for more information): & $\begin{array}{l}\text { http://plants.usda.gov/factsheet/pdf/fs_thin6. } \\
\text { pdf }\end{array}$ \\
\hline Mature height (ft): & 3 to $4 \mathrm{ft}$ \\
\hline Fire resistant (yes/no): & No \\
\hline Low growing (yes/no): & No \\
\hline Precipitation range (in.): & $\begin{array}{l}12 \text { to } 18 \text { in., not as drought tolerant as } \\
\text { crested wheatgrass, Siberian wheatgrass, } \\
\text { or Russian wildrye }\end{array}$ \\
\hline Minimum root depth (in.): & Fibrous \\
\hline $\begin{array}{l}\text { Aggressiveness (fast, medium, slow growth } \\
\text { rate): }\end{array}$ & Fast \\
\hline Wear tolerance for maneuver areas: & $\begin{array}{l}\text { Due to small rhizomes, intermediate } \\
\text { wheatgrass is very wear tolerant in a } 12 \text { to } \\
18 \text {-in. precipitation zone }\end{array}$ \\
\hline $\begin{array}{l}\text { Spread by rhizomes (may tolerate munitions } \\
\text { impacts): }\end{array}$ & Yes (moderate) \\
\hline Ecological bridge suitability: & $\begin{array}{l}\text { No, due to moderate rhizomes it creates } \\
\text { stands that tend to be closed to other spe- } \\
\text { cies. Excellent competitor against annual } \\
\text { weeds. }\end{array}$ \\
\hline Additional notes: & Some leaves stay green most of summer \\
\hline
\end{tabular}

\section{Thinopyrum intermedium}

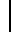

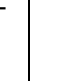


Needle-and-Thread grass

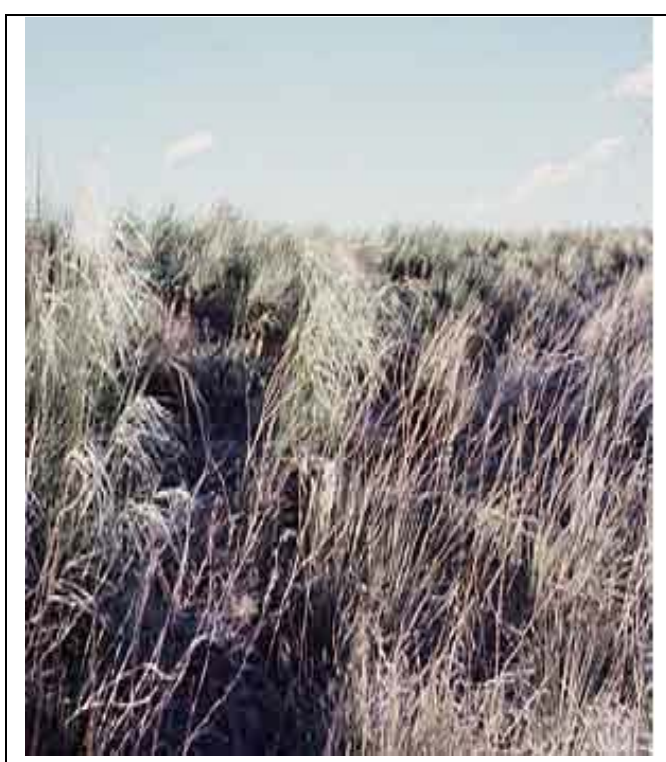

Web site and fact sheet (for more information):

Mature height (ft):

Fire resistant (yes/no)

Low growing (yes/no):

Precipitation range (in.):

Minimum root depth (in.):

Aggressiveness (fast, medium, slow growth rate):

Wear tolerance for maneuver areas:

Spread by rhizomes (may tolerate munitions impacts):

Ecological bridge suitability:

Additional notes:
Hesperostipa comata

Needle-and-thread is a native, tufted, coolseason grass common to the prairies, plains and foothills of the western United States. It is a perennial bunchgrass, 1 to 4 feet tall with erect, smooth culms and long, flat leaves 8 to 12 inches long. The inflorescence is a contracted panicle that remains partially in the sheath. The source of its name is the 4 to 5 inch long twisted awn which arises from the lemma. It detaches from the inflorescence with the seed and gives the appearance of a short needle and long thread. The ligule, an identifying characteristic, is membranous and split.

Photo by W. L. Wagner @ USDA-NRCS PLANTS Database

http://plants.usda.gov/plantguide/pdf/pg_heco26.pd f

1 to $4 \mathrm{ft}$

Yes

No

7 to 16 in.

No information available

Slow

No

No information available

No information available

Best adapted to sandy soils. Because of its broad range of adaptation, native seed mixtures should specify "Source Identified" seed from locations within 500 miles of the planting site. 
Russian wildrye

Psathyrostachys juncea

\begin{tabular}{|c|c|}
\hline & $\begin{array}{l}\text { Russian wildrye is a large, cool-season, introduced, } \\
\text { long-lived, perennial bunch grass. It has an abun- } \\
\text { dance of long, dense, basal leaves that are from } 6 \\
\text { to } 18 \text { inches long and up to } 1 / 4 \text { inch in width. } \\
\text { Plants vary from light to dark green, with many } \\
\text { shades of blue-green. } \\
\text { The erect, leafless reproductive stems are about } \\
30 \text { to } 40 \text { inches tall. The seedhead is a short } \\
\text { dense, erect spike with two or more short-awned } \\
\text { spikelets clustered at axis joints. The seed shatters } \\
\text { readily at maturity. The seed is about the same } \\
\text { size as crested wheatgrass seed. }\end{array}$ \\
\hline $6 x+4$ & $\begin{array}{l}\text { Photo by Larry Holzworth @ USDA-NRCS PLANTS } \\
\text { Database }\end{array}$ \\
\hline $\begin{array}{l}\text { Web site and fact sheet (for more in- } \\
\text { formation): }\end{array}$ & http://plants.usda.gov/plantguide/pdf/pg_psju3.pdf \\
\hline Mature height (ft): & 1 to $3 \mathrm{ft}$ \\
\hline Fire resistant (yes/no): & Yes, remains green throughout the summer \\
\hline Low growing (yes/no): & No \\
\hline Precipitation range (in.): & 8 to 16 in., can tolerate less rainfall than crested \\
\hline Minimum root depth (in.): & Fibrous \\
\hline $\begin{array}{l}\text { Aggressiveness (fast, medium, slow } \\
\text { growth rate): }\end{array}$ & $\begin{array}{l}\text { Slow establishment, often forms closed communi- } \\
\text { ties if stand establishment is successful }\end{array}$ \\
\hline Wear tolerance for maneuver areas: & Yes \\
\hline $\begin{array}{l}\text { Spread by rhizomes (may tolerate mu- } \\
\text { nitions impacts): }\end{array}$ & No \\
\hline Ecological bridge suitability: & Yes \\
\hline Additional notes: & Will not tolerate flooding. \\
\hline
\end{tabular}




\begin{tabular}{|c|c|}
\hline & $\begin{array}{l}\text { Sainfoin is an introduced perennial legume } \\
\text { with many tall hollow stems, } 60 \text { to } 80 \mathrm{~cm} \text { or } \\
\text { more. Its leaves are compound with } 5 \text { to } 14 \\
\text { pairs of oval-shaped leaflets and a single leaf- } \\
\text { let at the tip. Sainfoin has conelike clusters } \\
\text { fragrant, pinkish- red flowers on the end of long } \\
\text { stalks. Seedpods are flat and contain a single } \\
\text { dark olive green, brown, or black seed, } 4 \text { to } 6 \\
\mathrm{~mm} \text {. There are } 18,000 \text { seeds/pound. }\end{array}$ \\
\hline & $\begin{array}{l}\text { Photo by Richard Old, WTU Burke Herbarium @ } \\
\text { USDA-NRCS PLANTS Database }\end{array}$ \\
\hline $\begin{array}{l}\text { Web site and fact sheet (for more infor- } \\
\text { mation): }\end{array}$ & http://plants.usda.gov/factsheet/pdf/fs_onvi.pdf \\
\hline Mature height (ft): & 3 to $4 \mathrm{ft}$ \\
\hline Fire resistant (yes/no): & Yes, stays green during the summer \\
\hline Low growing (yes/no): & No \\
\hline Precipitation range (in.): & 14 in. or greater \\
\hline Minimum root depth (in.): & Deep rooted \\
\hline $\begin{array}{l}\text { Aggressiveness (fast, medium, slow } \\
\text { growth rate): }\end{array}$ & No information available \\
\hline Wear tolerance for maneuver areas: & No information available \\
\hline $\begin{array}{l}\text { Spread by rhizomes (may tolerate muni- } \\
\text { tions impacts): }\end{array}$ & No information available \\
\hline Ecological bridge suitability: & No information available \\
\hline Additional notes: & $\begin{array}{l}\text { Regrowth is poor so questionable if suitable for } \\
\text { military training lands. Sainfoin is a non-bloat } \\
\text { legume. Sainfoin has a deep taproot. Com- } \\
\text { petes fairly well in mixed communities. }\end{array}$ \\
\hline
\end{tabular}


Sandberg bluegrass

Poa secunda

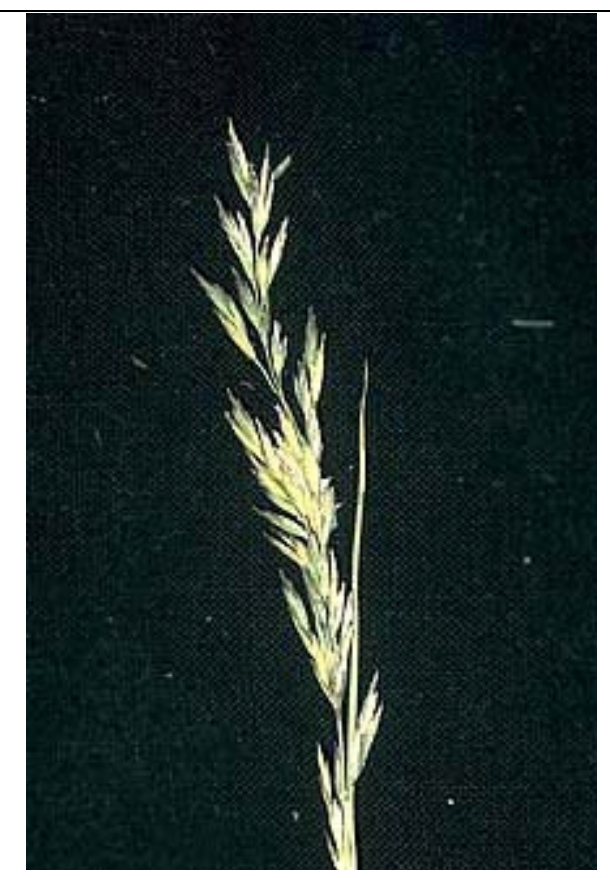

Sandberg bluegrass is a long-lived perennial and is one of the native bluegrasses that is an important component of the sagebrush grassland vegetation in the western United States. Sandberg bluegrass begins growth early in spring, before crested wheatgrass, and matures in early summer unless moisture is sufficient to keep it green all summer. In this respect it is the most persistent of all the cool season grasses. It is a pioneer species, one of the first grasses to colonize on disturbed sites. Plants of the Sandberg bluegrass complex occupy a niche in bunchgrass plant communities. The primary area of use would include the northern Great Plains (Montana, Wyoming, North Dakota, South Dakota, Colorado), the Intermountain West including the Great Basin (Idaho, Nevada, Oregon, Washington, Utah), and the Palouse country (Idaho, Oregon, Washington).

Photo by Robert H. Mohlenbrock @ USDA-NRCS PLANTS Database

Web site and fact sheet for Poa http://plants.usda.gov/factsheet/pdf/fs_pose.pdf secunda (for more information): Mature height (ft): 2 to $4 \mathrm{ft}$, but seldom that tall on military lands; generally short growing.

\begin{tabular}{|l|l|}
\hline Fire resistant (yes/no): & Yes \\
\hline Low growing (yes/no): & Yes \\
\hline Precipitation range (in.): & 1 \\
\hline Minimum root depth (in.): & 4 \\
\hline $\begin{array}{l}\text { Aggressiveness (fast, medium, slow } \\
\text { growth rate): }\end{array}$ & M \\
\hline Wear tolerance for maneuver areas: & Yes \\
\hline $\begin{array}{l}\text { Spread by rhizomes (may tolerate muni- } \\
\text { tions impacts): }\end{array}$ & Yes \\
\hline Ecological bridge suitability: & San
\end{tabular}

Additional notes:

Sandberg can coexist with other species and add biodiversity to those plant communities

This species is known to be one of the first returning species after land is disturbed after a training event, probably because of its early maturity and apparent dormancy during the summer and fall period. It occupies space in bunchgrass plant communities and assists with deterring invasive species encroachment due to its extensive root system. 
Shadscale saltbush

\begin{tabular}{|c|c|}
\hline & $\begin{array}{l}\text { The shadscale saltbush is generally described as a per- } \\
\text { ennial shrub. This dicot (dicotyledon) is native to the U.S. } \\
\text { and has its most active growth period in the Spring and } \\
\text { Summer. Leaves are not retained year to year. The shad- } \\
\text { scale saltbush has a slow growth rate. At maturity, the } \\
\text { typical shadscale saltbush will reach up to } 3 \mathrm{ft} \text { high, with a } \\
\text { maximum height at } 20 \text { years of } 3 \mathrm{ft} \text {. }\end{array}$ \\
\hline & Photo by AI Schneider @ USDA-NRCS PLANTS Database \\
\hline $\begin{array}{l}\text { Web site and fact sheet (for } \\
\text { more information): }\end{array}$ & $\begin{array}{l}\text { http://plants.usda.gov/java/profile?symbol=ATC0\&photolD=atco } \\
\text { _005_avp.tif }\end{array}$ \\
\hline Mature height (ft): & 1 to $3 \mathrm{ft}$ \\
\hline Fire resistant (yes/no): & No information available \\
\hline Low growing (yes/no): & Shrub \\
\hline Precipitation range (in.): & 5 to 10 in. \\
\hline Minimum root depth (in.): & No information available \\
\hline $\begin{array}{l}\text { Aggressiveness (fast, medium, } \\
\text { slow growth rate): }\end{array}$ & No information available \\
\hline $\begin{array}{l}\text { Wear tolerance for maneuver } \\
\text { areas: }\end{array}$ & No information available \\
\hline $\begin{array}{l}\text { Spread by rhizomes (may toler- } \\
\text { ate munitions impacts): }\end{array}$ & No information available \\
\hline Ecological bridge suitability: & Not applicable (a shrub) \\
\hline Additional notes: & \\
\hline
\end{tabular}

Atriplex confertifolia 


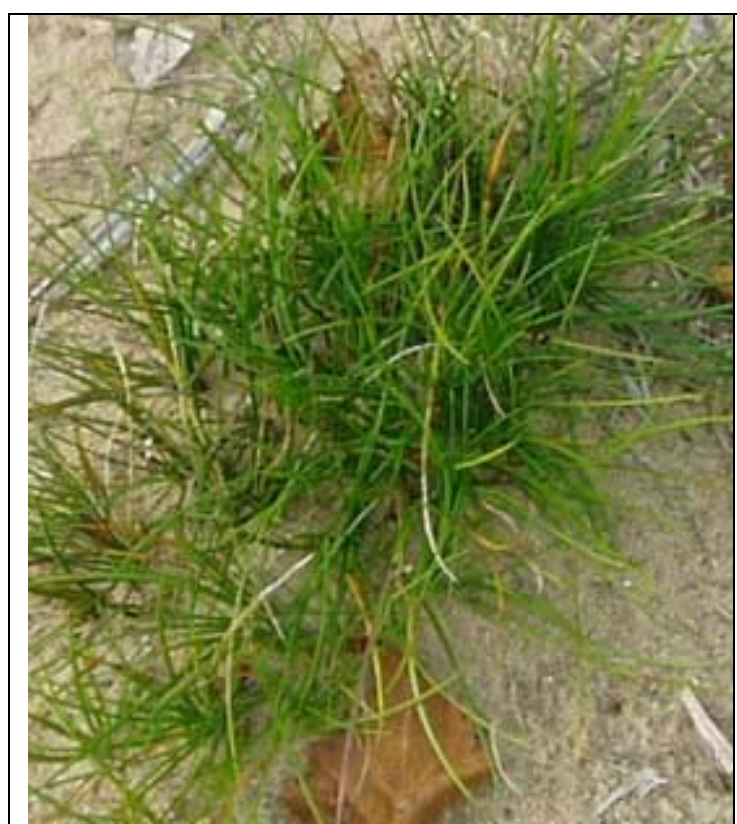

Web site and fact sheet (for more information):

Mature height $(\mathrm{ft})$ :

Fire resistant (yes/no):

Low growing (yes/no):

Precipitation range (in.):

Minimum root depth (in.):

Aggressiveness (fast, medium, slow growth rate):

Wear tolerance for maneuver areas:

Spread by rhizomes (may tolerate munitions impacts):

Ecological bridge suitability:

Additional notes:
Native, long-lived, cool-season species indigenous to the Northern Hemisphere. Adapted to open, exposed, high altitude sites in Rocky Mountain and northern Intermountain area with over 8 to 10 " precipitation. Tolerant of shallow, gravely, and dry, weakly saline and acid soils. Cold and drought tolerant.

ERDC-CRREL photo

http://plants.usda.gov/java/charProfile?symbol= FEOV $0.5 \mathrm{ft}$ Yes Yes 12 to $30 \mathrm{in.}$ Fibrous

Slow

Yes

No

Yes

Short growing grass. Some accessions are native and some accessions are introduced from Europe. Has been successfully seeded in native mixtures where a competitive, lowgrowing ground cover is required. Very competitive with annual weeds. Abundant fibrous roots. 


\section{Siberian wheatgrass}

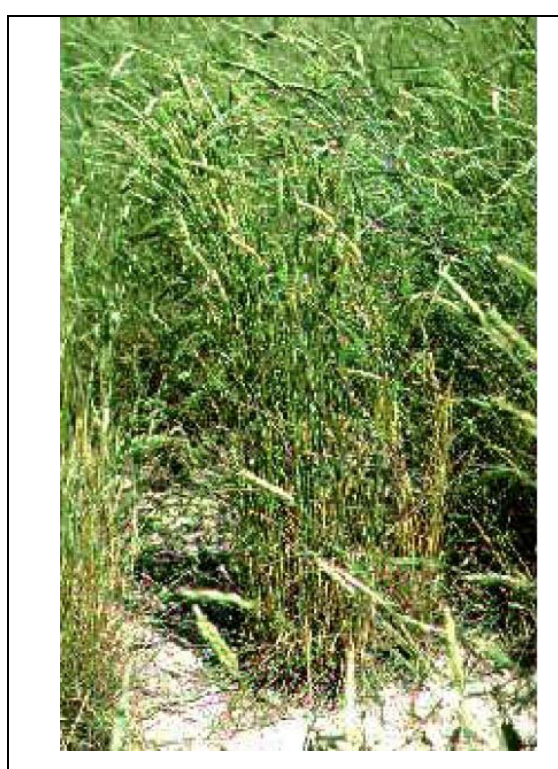

Web site and fact sheet (for more information):

Mature height (ft):

Fire resistant (yes/no):

Low growing (yes/no):

Precipitation range (in.):

Minimum root depth (in.):

Aggressiveness (fast, medium, slow growth rate):

Wear tolerance for maneuver areas: Spread by rhizomes (may tolerate munitions impacts):

Ecological bridge suitability:

Additional notes:

\section{Agropyron fragile}

Siberian wheatgrass is a perennial grasses commonly seeded in the western United States. It is long-lived, cool season, drought tolerant, introduced grasses with extensive root systems. Siberian wheatgrass grows from 1 to 3 feet tall and seed spikes may be 1.5 to 3 inches long. Spikelets flattened, closely overlapping, located divergent (flatwise) at a slight angle on the rachis flower stem. The lemmas generally narrow to a short awn and glumes are firm, keeled, tapering into a short bristle. Culms are erect, in a dense tuft and leafy. Leaves are flat, smooth below, slightly coarse above, and vary in width from 2 to $6 \mathrm{~mm}$.

Photo by Loren St. John @ USDA-NRCS PLANTS Database http://plants.usda.gov/factsheet/pdf/fs_agfr.pdf 1 to $3 \mathrm{ft}$

Yes, retains greenness better than crested wheatgrass.

No

8 to 14 in.

Fibrous, extensive

Rapid seedling establishment, adapted to sandy soils, and will outcompete most invasive weedy annuals.

Yes, especially on better adapted sites No

When seeded as a minor component under the ecological bridge concept, Siberian wheatgrass is compatible with other native grasses. Suggested seeding rate is generally $2 \mathrm{lb} /$ acre or less in this situation.

Will not tolerate flooding. Can withstand heavy grazing; therefore has regrowth capacity after maneuver damage. Six inches of new growth should be attained before training is allowed. Was able to retard encroachment of cheatgrass in tracked vehicle test at Yakima Training Center. 


\section{Slender wheatgrass}

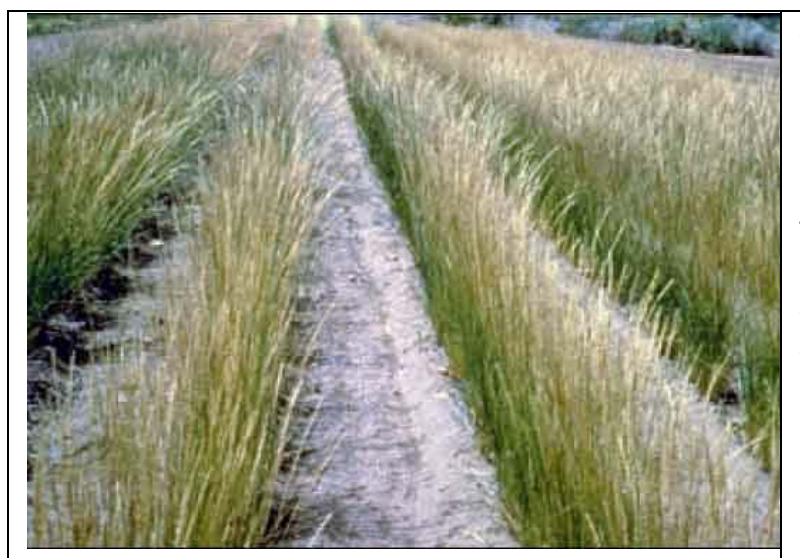

Web site and fact sheet (for more information):

Mature height (ft):

Fire resistant (yes/no):

Low growing (yes/no):

Precipitation range (in.):

Minimum root depth (in.):

Aggressiveness (fast, medium, slow growth rate):

Wear tolerance for maneuver areas:

Spread by rhizomes (may tolerate munitions impacts):

Ecological bridge suitability:

Additional notes:

\section{Elymus trachycaulus}

Slender wheatgrass is an erect, tufted bunchgrass ranging in height from 2 to 2.5 feet. It is a relatively short-lived ( 3 to 4 years) cool season perennial species native to the mountain and intermountain areas of the western United States and the northern Great Plains. It has very short rhizomes and the seedstalks and stems have a characteristic reddish to purplish tinge at the base.

Photo by Upper Colorado Environmental Plant Center, Meeker, CO @ USDA-NRCS PLANTS Database

http://plants.usda.gov/factsheet/pdf/fs_eltr 7.pdf

2 to $3 \mathrm{ft}$

No

No

$>14$ in.

Fibrous

Fast and really aggressive, good seedling vigor and establishment qualities

Yes, for up to three years after planting No

Best suited as a filler component in seed mixtures containing slower establishing, long-lived perennials.

Seedlings are vigorous and provide good initial plant cover in seed mixtures.

Plants tend to be short-lived, thus giving other plants a chance to become established. A relatively short-lived species, but it reseeds and spreads well by natural seeding. Seedlings are vigorous and capable of establishing on harsh sites. Was one of the first native grasses included in early restoration plantings. Is used primarily to restore disturbances and rehabilitate native communities. 


\begin{tabular}{|c|c|}
\hline & $\begin{array}{l}\text { Small burnet is a hardy, relatively long-lived, ever- } \\
\text { green, introduced, perennial forb. It is usually a } \\
\text { branched caudex (thick base of stems) with a promi- } \\
\text { nent tap root and sometimes weakly rhizomatous. } \\
\text { Small burnet plants have alternate pinnately com- } \\
\text { pound leaves. Leaflets are mostly } 9 \text { to } 17 \text {, oval to ob- } \\
\text { long, } 4 \text { inches long and coarsely toothed. Total height } \\
\text { varies from } 6 \text { inches on droughty sites to approxi- } \\
\text { mately } 25 \text { inches on irrigated sites. The flowers are } \\
\text { closely packed in headlike to elongate spikes } 3 \text { to } 8 \\
\text { inches long. The flowers are mostly imperfect, the } \\
\text { lower ones male and the upper ones female with no } \\
\text { petals and about } 12 \text { stamens. Native burnet species } \\
\text { have } 2 \text { to } 4 \text { stamens. }\end{array}$ \\
\hline & Photo by Joe F. Duft @ USDA-NRCS PLANTS Database \\
\hline $\begin{array}{l}\text { Web site and fact sheet (for more } \\
\text { information): }\end{array}$ & http://plants.usda.gov/factsheet/pdf/fs_sami3.pdf \\
\hline Mature height $(\mathrm{ft})$ : & From $0.5 \mathrm{ft}$ on droughty sites to $2 \mathrm{ft}$ when irrigated \\
\hline Fire resistant (yes/no): & Yes (evergreen) \\
\hline Low growing (yes/no): & Yes on droughty sites(forb) \\
\hline Precipitation range (in.): & 14 to 20 in. \\
\hline Minimum root depth (in.): & Has tap root \\
\hline $\begin{array}{l}\text { Aggressiveness (fast, medium, slow } \\
\text { growth rate): }\end{array}$ & Medium \\
\hline $\begin{array}{l}\text { Wear tolerance for maneuver ar- } \\
\text { eas: }\end{array}$ & Weakly rhizomatous \\
\hline $\begin{array}{l}\text { Spread by rhizomes (may tolerate } \\
\text { munitions impacts): }\end{array}$ & No information available \\
\hline Ecological bridge suitability: & Yes \\
\hline Additional notes: & $\begin{array}{l}\text { Noted for value in mixes for erosion control and beau- } \\
\text { tification values. Leaves and stems stay green with } \\
\text { relatively high moisture content during the fire sea- } \\
\text { son. Growth of small burnet begins in early spring so } \\
\text { may be competitive with annual invasive weeds. Can } \\
\text { compete fairly well with cheatgrass. Can be seeded, } \\
\text { grazed, and maintained in mixed grass and broadleaf } \\
\text { herb plantings. If seeded in mixtures with perennial } \\
\text { grasses, the species can diminish in density over } \\
\text { time. Will draw in wildlife and livestock (ice cream } \\
\text { plant). }\end{array}$ \\
\hline
\end{tabular}


Snake River wheatgrass

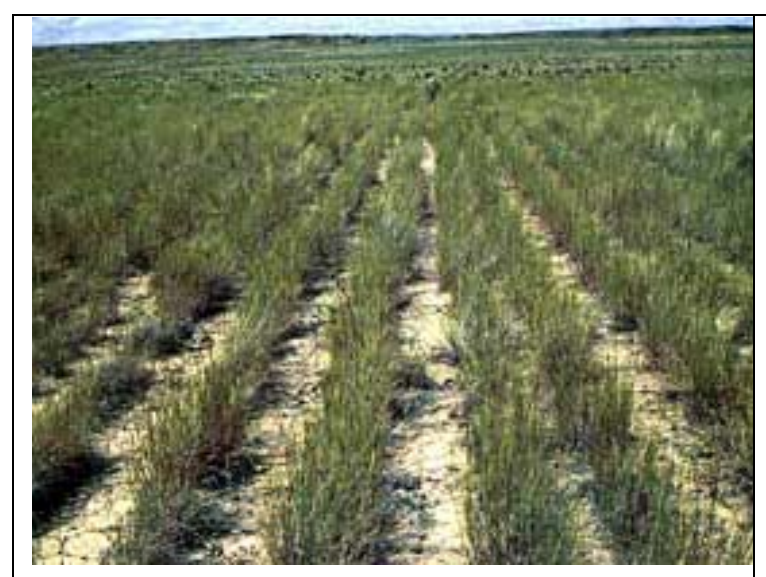

ERDC-CRREL photo

\section{Elymus wawawaiensis}

Snake River wheatgrass is very well adapted in the northwest, especially at Yakima Training Center. It is a long-lived, perennial bunchgrass that is native to the valleys of the Snake River and its tributaries in Oregon, Washington and northern Idaho. Morphologically, this taxon is almost identical to bluebunch wheatgrass, but genetically it is similar to thickspike wheatgrass. It is adaptable to most areas suitable for bluebunch wheatgrass, but is more vigorous and productive. Snake River wheatgrass has been successfully established on sites that receive as little as 200 $\mathrm{mm}$ of annual precipitation. At many sites, Snake River wheatgrass grows in grass mixtures with unawned forms of bluebunch wheatgrass. At such sites, Snake River wheatgrass is easily distinguished by its awns.

\begin{tabular}{|l|l|}
\hline Web site and fact sheet (for more information): & $\begin{array}{l}\text { http://plants.usda.gov/java/profile?symbol=EL } \\
\text { WA2 }\end{array}$ \\
\hline Mature height (ft): & 1.5 to $4 \mathrm{ft}$ \\
\hline Fire resistant (yes/no): & No \\
\hline Low growing (yes/no): & No \\
\hline Precipitation range (in.): & 10 to 20 in. \\
\hline Minimum root depth (in.): & Fibrous \\
\hline $\begin{array}{l}\text { Aggressiveness (fast, medium, slow growth } \\
\text { rate): }\end{array}$ & Good seedling vigor \\
\hline Wear tolerance for maneuver areas: & Yes \\
\hline $\begin{array}{l}\text { Spread by rhizomes (may tolerate munitions } \\
\text { impacts): }\end{array}$ & No rhizomes \\
\hline Ecological bridge suitability: & $\begin{array}{l}\text { Yes, very compatible with slower develop- } \\
\text { ing natives such as thickspike wheatgrass, } \\
\text { western wheatgrass, bluegrass species, } \\
\text { and needlegrass species; does compete } \\
\text { well with aggressive introduced grasses if } \\
\text { seeded heavy. }\end{array}$ \\
\hline Additional notes: & $\begin{array}{l}\text { Was able to retard encroachment of cheat- } \\
\text { grass in tracked vehicle test at Yakima } \\
\text { Training Center. }\end{array}$ \\
\hline
\end{tabular}


Tall wheatgrass

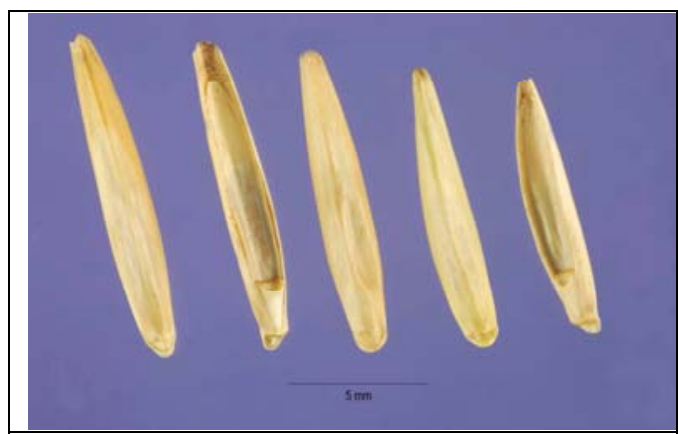

Web site and fact sheet (for more information):

Mature height (ft):

Fire resistant (yes/no):

Low growing (yes/no):

Precipitation range (in.):

Minimum root depth (in.):

Aggressiveness (fast, medium, slow growth rate):

Wear tolerance for maneuver areas:

Spread by rhizomes (may tolerate munitions impacts):

Ecological bridge suitability:

Additional notes:
Thinopyrum ponticum

Tall wheatgrass is a tall, long-lived perennial bunchgrass reaching 1 to $3 \mathrm{~m}$ ( 3 to $10 \mathrm{ft}$ ) tall. Tall wheatgrass is originally from Turkey, Asia Minor, and Russia.

Photo by Steve Hurst @ USDA-NRCS PLANTS

Database

http://plants.usda.gov/java/charProfile?symbol=THP $\underline{07}$ 4 to $6 \mathrm{ft}$ No No 12 in.

Fibrous

Excellent establishment, saline tolerant, and defoliation tolerant

No information available

No information available

Suitable




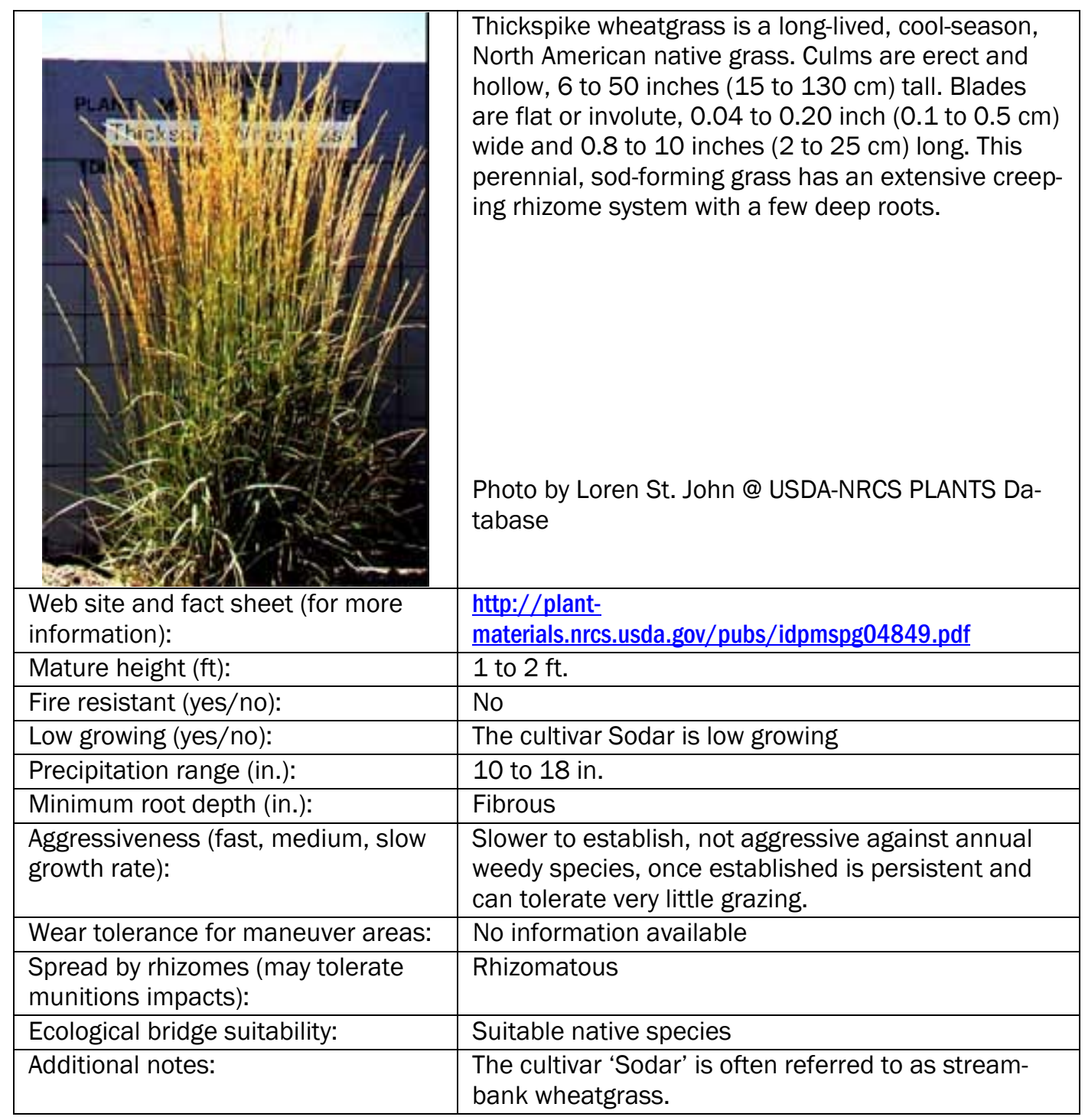


Western wheatgrass

Pascopyrum smithii

\begin{tabular}{|c|c|}
\hline & $\begin{array}{l}\text { Western wheatgrass is perhaps one of the best known } \\
\text { and most commonly used native grasses. It is a long- } \\
\text { lived, cool season species that has coarse blue- green } \\
\text { leaves with prominent veins. It is a sod former with very } \\
\text { strong, spreading rhizomes. Stems arise singly or in } \\
\text { clusters of a few and reach heights of } 1 \text { to } 3 \text { feet. The } \\
\text { sheaths are hairy and the purplish auricles typically } \\
\text { clasp the stem. The seed spike is erect and about } 2 \text { to } \\
6 \text { inches long. } \\
\text { Photos by Robert H. Mohlenbrock @ USDA-NRCS } \\
\text { PLANTS Database }\end{array}$ \\
\hline Web site and fact sheet: & http://plants.usda.gov/factsheet/pdf/fs_pasm.pdf \\
\hline Mature height (ft): & 1 to $3 \mathrm{ft}$. \\
\hline Fire resistant (yes/no): & $\begin{array}{l}\text { Tolerant to fire in dormant stage. Greens up later than } \\
\text { other species. }\end{array}$ \\
\hline Low growing (yes/no): & Yes \\
\hline Precipitation range (in.): & 12 to $20 \mathrm{in.}$ \\
\hline Minimum root depth (in.): & Fibrous \\
\hline $\begin{array}{l}\text { Aggressiveness (fast, medium, } \\
\text { slow growth rate): }\end{array}$ & $\begin{array}{l}\text { Slow to start and has poor germination so stands are } \\
\text { developed through spread of rhizomes instead of opti- } \\
\text { mum seed germination. }\end{array}$ \\
\hline $\begin{array}{l}\text { Wear tolerance for maneuver } \\
\text { areas: }\end{array}$ & $\begin{array}{l}\text { Yes, damage is repaired by vegetative spread from rhi- } \\
\text { zomes }\end{array}$ \\
\hline $\begin{array}{l}\text { Spread by rhizomes (may tolerate } \\
\text { munitions impacts): }\end{array}$ & Yes \\
\hline Ecological bridge suitability: & $\begin{array}{l}\text { Does not compete well with aggressive introduced } \\
\text { grasses during establishment. }\end{array}$ \\
\hline Additional notes: & $\begin{array}{l}\text { Flood and silt tolerant. Can spread into adjoining plant } \\
\text { communities under ideal weather conditions. Unreliable } \\
\text { seedling establishment. Plants spread quickly from rhi- } \\
\text { zomes. Grows in association with native grasses on } \\
\text { sites that have been seriously altered and are occupied } \\
\text { by annual weeds. It can be seeded with bluebunch and } \\
\text { slender wheatgrasses, bottlebrush squirreltail, } \\
\text { Sandberg bluegrass, and related broadleaf forbs to re- } \\
\text { establish native communities and promote secondary } \\
\text { succession. Recovers from wildfires and prescribed } \\
\text { burning through rhizome proliferation. }\end{array}$ \\
\hline
\end{tabular}




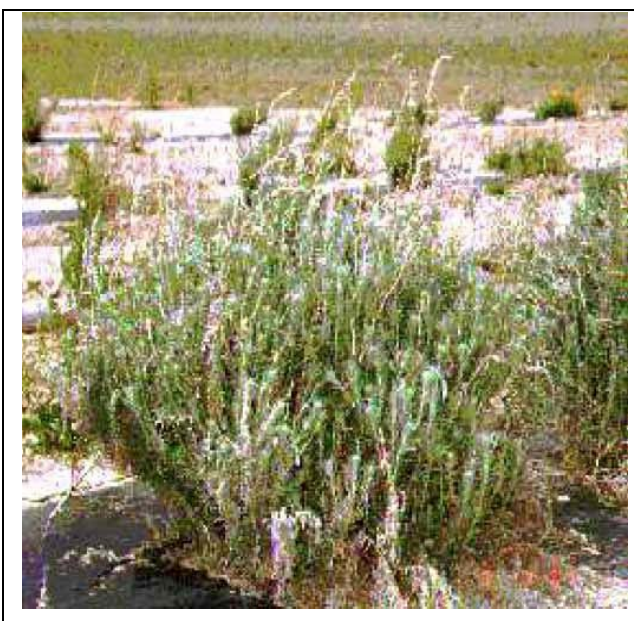

Photo by Loren St. John @ USDA-NRCS PLANTS Database

Web site and fact sheet (for more information):

Mature height (ft):

Fire resistant (yes/no):

Low growing (yes/no):

Precipitation range (in.):

Minimum root depth (in.):

Aggressiveness (fast, medium, slow

growth rate):

Wear tolerance for maneuver areas:

Spread by rhizomes (may tolerate muni-

tions impacts):

Ecological bridge suitability:

Additional notes:
Winterfat is an erect to spreading, low-growing, long-lived half-shrub native to the western United States. It is a cool season plant, typically with a central woody stem arising from a woody crown. Annual secondary stems, 8 inches to 4 feet and sometimes taller, are herbaceous on dwarf forms and herbaceous to woody throughout on taller forms, wooly and branched. Winterfat has an extensive fibrous root system and a deep penetrating taproot. Leaves are simple, alternate, mostly linear, and revolutely margined (rolled back from the margin). The inflorescence is a spike. Plants are monoecious with staminate flowers above the pistillate ones or occasionally they are dioecious. Pollination usually occurs between plants, but self-pollination may occur on monecious plants. Wind is the principal mode of pollination. The seed is a utricle and the seed coat is thin and covered with fine white, silky pilose hairs to $1 / 2$ inch long. http://plants.usda.gov/plantguide/pdf/pg_krla2.pdf 1 to $4 \mathrm{ft}$ depending on site and seed source No No 6 to 16 in. Deep taproot and an extensive fibrous root system near the soil surface No information available

Germinates readily and provides fairly rapid growth under favorable growing conditions No information available

No information available




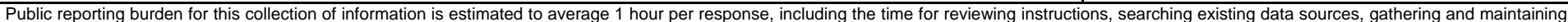

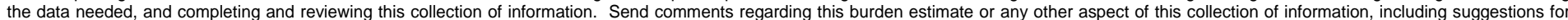

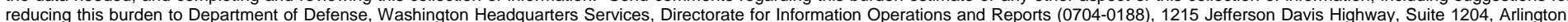

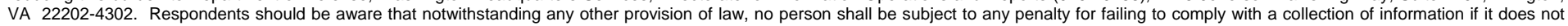
display a currently valid OMB control number. PLEASE DO NOT RETURN YOUR FORM TO THE ABOVE ADDRESS.
1. REPORT DATE (DD-MM-YYYY) 2. REPORT TYPE
3. DATES COVERED (From - To) June 2009 Final

4. TITLE AND SUBTITLE

Intermountain West Military Training Lands Planting Guide:

Selecting Seed Mixtures for Actively Used Military Lands

5a. CONTRACT NUMBER

5b. GRANT NUMBER

5c. PROGRAM ELEMENT NUMBER

\section{AUTHOR(S)}

Antonio J. Palazzo, Susan E. Hardy, Timothy J. Cary,

Kay H. Asay, and Kevin B. Jensen

5d. PROJECT NUMBER

5e. TASK NUMBER

5f. WORK UNIT NUMBER

\section{PERFORMING ORGANIZATION NAME(S) AND ADDRESS(ES)}

U.S. Army Engineer Research and Development Center Cold Regions Research and Engineering Laboratory

72 Lyme Road

Hanover, NJ 03755-1290

8. PERFORMING ORGANIZATION REPORT NUMBER

ERDC/CRREL TR-09-9

\section{SPONSORING I MONITORING AGENCY NAME(S) AND ADDRESS(ES)}

Environmental Security Technology Certification Program

SERDP/ESTCP Program Manager Compliance/Conservation

SERDP Program Office, 901 North Stuart Street, Suite 303, Arlington, VA 22203

10. SPONSOR/MONITOR'S ACRONYM(S)

ESTCP and AEC

11. SPONSOR/MONITOR'S REPORT NUMBER(S)

Army Environmental Command

ATTN: SFIM-AEC-PCT 5179 Hoadley Rd.

Aberdeen Proving Ground, MD 21010-5401

\section{DISTRIBUTION I AVAILABILITY STATEMENT}

Approved for public release; distribution is unlimited.

\section{SUPPLEMENTARY NOTES}

\section{ABSTRACT}

These guidelines were prepared to help military land managers select appropriate seed mixtures for revegetation on actively used training lands in the Intermountain West of the United States. Recommending a seed mixture is complicated because of the various ecosystems, land uses, soils, and plant selection goals. We wanted to keep the guidelines as simple as possible but still be able to recommend seed mixtures adapted for this region. We have broken down the process into four steps that we feel cover the important aspects of selecting the most adapted seed mixture to meet revegetation goals on actively used lands such as training ranges, airfields, and MOUT sites. Tables provide information to assist in selection of species to include in seed mixtures for various soil types, climates, and land usage. Characteristics of the militarily important plants mentioned in this guide are also given. This information is provided in two appendices containing a summary table and individual plant description sheets.

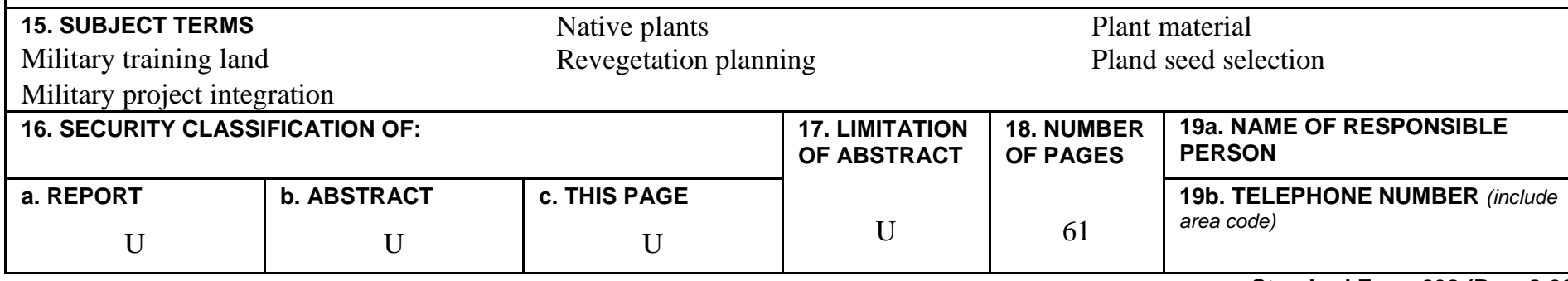

